\title{
Land use land cover dynamics through time and their proximate drivers of change in a tropical mountain system: a case study in a highland landscape of northern Ecuador Land use transitions and drivers of change in a highland landscape of northern Ecuador
}

Paulina Guarderas ${ }^{1,2}$, Franz Smith $^{3}$, Marc Dufrene ${ }^{2}$

${ }^{1}$ Facultad de Ciencias Biológicas, Universidad Central del Ecuador, Quito, Ecuador

${ }^{2}$ Biodiversity and Landscape, TERRA, Teaching and Research Center, Gembloux Agro-Bio Tech, University of Liege, Gembloux, Belgium,

${ }^{3}$ Colegio de Ciencias Biológicas y Ambientales, Universidad San Francisco de Quito, Quito, Ecuador

*Paulina Guarderas

Email: apguarderas@uce.edu.ec 


\section{Abstract}

2 Tropical mountain ecosystems are threatened by land use pressures, reducing the capacity of ecosystems to provide a large diversity of benefits to people and to be able to achieve them in the

4 long term. The analysis of land use pressures is often superficial and very general, although they are characterized by numerous interactions and strong differences in their local dynamics. We used a variety of freely available geospatial and temporal data and methods to assess and explain patterns of land use land cover (LULC) change, focusing on native ecosystem dynamics, in a sensitive region of the northern Ecuadorian Andes. Our results demonstrate a dynamic and clear geographical pattern of distinct LULC transitions through time, explained by different combination of socio-economic factors, pressure variables and environmental parameters, from which ecological context variables, such as slope and elevation, were the main drivers of change in this landscape. We found that deforestation of remnant native forest and agricultural expansion still occur in higher elevations located, while land conversion toward anthropic environments were observed in lower elevations to the east of the studied territory. Our findings also reveal an unexpected stability trend of paramo and a successional recovery of previous agricultural land to the west and center of the territory which could be explained by agricultural land abandonment. However, the very low probability of persistence of montane forests in most of the studied landscape, highlights the risk that the remnant montane forests will be permanently lost in a few years, posing a greater threat to the already vulnerable biodiversity and limiting the capacity ecosystem service provisioning. The dynamic patterns through space and time and their explanatory drivers, found in our study, could help improve sustainably resource land management in vulnerable landscapes such as the tropical Andes in northern Ecuador. 


\section{Introduction}

26 Tropical mountain systems supply vital ecosystem services to millions of upland and lowland

27 inhabitants [1,2], but are increasingly being transformed by human activities [3,4]. Tropical

28 Andean mountain ecosystems are global hotspots of tropical biodiversity and habitat refugia

$29[4,5]$ and are threatened by agricultural expansion and intensification, urbanization, pollution,

30 mining, among other human activities, reducing the capacity of these ecosystems to provide a

31 large diversity of benefits to people and guarantee their long-term sustainability.

32 Although the millennial human presence in the Andean mountain systems has impacted the

33 history of landscape patterns in this region, mainly shaped by intensive traditional agriculture,

34 which has been practiced for centuries [6], recent land-change patterns have been documented in

35 this region [7-10], demonstrating varying patterns of landscape dynamism and heterogeneity

36 [11]. Deforestation and agricultural intensification are the dominant transitions in many Andean

37 systems [8,9], but forest recovery due to agricultural de-intensification and transitions between

38 crops, pastures, and secondary vegetation have also been observed in these systems, yet in-depth

39 multi-temporal change approaches are required to better understand this complexity in order to

40 balance biodiversity conservation with human needs $[7,9,12]$.

41 Distinct land use and land cover conversion (LULCC) patterns observed in the tropical Andes

42 vary along demographic, socio-economic, cultural and technological factors that interact with

43 biophysical features like elevation, topography, soils and climate parameters [3,13-15],

44 operating across spatial, temporal, and organizational scales $[13,14,16]$. For example, increasing

45 global demand for food and non-food crops can drive agriculture expansion in more fertile and

46 flat land [7,17-19], where natural ecosystem recovery has been observed in abandoned marginal

47 agricultural land [3,19,20]. 
Despite the documented useful insights on how different drivers can influence LULCC on specific landscape mosaics in tropical mountain systems, evidence from synthetical studies suggests that no universal link between cause and effect exists to explain LULCC, especially

51 deforestation in tropical systems, where different combinations of various proximate causes and

52 underlying driving forces in varying geographical and historical contexts could affect landscape

53 changes $[17,21]$.

54 Part of the key to understanding future changes in tropical mountain systems may come from

55 better understanding LULCC pattern-dynamics across environmental gradients and along

56 different temporal scales, in addition to deciphering the interactive effects of distinct

57 anthropogenic influences on these kinds of processes [3], which could be exacerbated, given the

58 high vulnerability to climate change of highland landscapes like the Ecuadorian Andes [22].

59 Understanding this complexity is fundamental for the development of policies and measures for

60 landscape planning and management in highland ecosystems, where biodiversity conservation,

61 sustainable use of natural resources and the supply of essential ecosystem services (eg. water or

62 food) should be assured [23,24] not only for local inhabitants but also for downstream

63 populations[19].

64 This study is unique in that it uses a variety of geospatial and temporal data and methods to

65 assess and explain patterns of LULCC in a sensitive region of the northeastern Ecuadorian

66 Andes, which comprises a landscape with distinct climatic conditions and management regimes

67 along its elevation gradient, where floriculture crops and urban centres are emerging in an

68 agricultural matrix, posing more pressure to remnant native ecosystems and their services.

69 The objective of this paper was to assess the role of different drivers on LULCC in a highland

70 landscape of Northern Ecuador from 1990 to 2014, using the Driver-Pressure-State-Impact- 
71 Response (DPSIR) framework [25]. To achieve this objective, we addressed two specific

72 questions: (1) what are the LULCC patterns across geographic and biophysical settings through

73 time, emphasizing in trends on native ecosystems as sentinel habitats, specifically how

74 landscapes are being transformed over time, in terms of the rate, magnitude and direction of

75 those changes and (2) what is the combination of environmental and anthropic factors that better

76 explain the different landscape transitions.

\section{Materials and methods}

\section{Study area}

79 Pedro Moncayo county is located in the western branch of the Andes in northern Ecuador (Fig

80 1). This county is characterized by a wide elevation gradient (2400- $4400 \mathrm{~m}$ a.s.l) and a

81 management regime that varies in intensity depending on the elevation [26]. The higher

82 altitudinal zone (above $3300 \mathrm{~m}$ ) is dominated by native ecosystems, represented by paramo and

83 highland montane forests [27]. The middle altitudinal area (2800 -3300) has been intensively

84 used for agriculture and livestock through time, causing severe soil degradation [27,28] and the

85 lower lands are characterized by a shrub dominated dry ecosystems (Figs 1 and 2).

86 Fig. 1. Location of study area (Pedro Moncayo county).

87 The studied territory has a total surface area of $339 \mathrm{~km}^{2}$, which is divided into 5 parishes that

88 have an east to west geographic arrangement, depicting the same elevation belts previously

89 described (Fig 1), however show different levels of production development and population

90 trends; parishes located to the west portray a local economy based on subsistence agriculture and

91 lower population growth, whereas the eastern parishes are attracting a growing population, have

92 a more concentrated urban development, more irrigation systems and it harbors an expanding

93 agro-industrial sector [26]. 
94 Pedro Moncayo is characterised by a typical climate of the tropical Andean region, with low

95 annual variability but significant changes between night and day [29], in addition because of its

96 elevation gradient, quarterly midday maximum temperatures could range from $14^{\circ} \mathrm{C}$ to $24^{\circ} \mathrm{C}$

97 and minimum nighttime temperatures could range from $4^{\circ} \mathrm{C}$ to $17^{\circ} \mathrm{C}$ [29]. In contrast, the

98 precipitation pattern follows a bimodal peak of heavy rains concentrated from October to

99 November and April to May, followed by a dry period of low precipitation from June to

100 September; quarterly precipitation could range from $0 \mathrm{~mm}$ to $225 \mathrm{~mm}$, and depending on the

101 season, the extension of the territory could shift to a different hydrologic regime [29]. For

102 instance, from April to June the majority of the territory could have more than $200 \mathrm{~mm}$ of

103 precipitation, whereas in the quarter of July to September most of the area receives less than 75

$104 \mathrm{~mm}$ of precipitation [29].

105 Approximately $4 \%$ of the county`s territory is under conservation or environmental

106 management, including the Jerusalem Protected Forest which occupies 1110 hectares of dry

107 ecosystems in the county's lowlands, and the Mojanda Lacustric complex, protecting only 26

108 hectares of highland ecosystems and water sources (Fig 1) [30].

109 Although, at present the majority (58.1\%) of the territory of Pedro Moncayo is dedicated to

110 traditional agricultural activities mainly for growing cereals, maize and potatoes, the economy of

111 the region is based on the production and export of flowers (mainly roses) using greenhouse

112 infrastructures [30]; small and medium-scale agriculture and livestock ranching are lower in

113 terms of labor absorption, technology incorporation and productivity [27].

\section{LULC datasets}

115 Official Land Use Land Cover (LULC) maps from the Ministry of Environment of Ecuador

116 (MAE) of four periods of time: 1990, 2000, 2008 and 2014 were used to generate polygon vector 
117 from Landsat (TM) images with a spatial resolution of 30 meters and a temporal resolution of 16

118 days [31]. The LULC official classification encompasses a 2-level hierarchical scheme, based

119 on the IPPC classes in combination with a taxonomy agreed by the entities in charge of

120 generating land cover information in Ecuador [31]. Despite possible drawbacks to the LULC

121 datasets, such as the existence of classification errors and uncertainties [32], its accessibility and

122 availability at different time spans offer considerable advantages for studying land cover changes

$123[33]$.

124 Five typologies not well represented in the official LULC dataset for the study region were 125 digitised to improve map accuracy [34]. These included: planted forests, developed areas

126 (populated zones), horticulture (areas represented by greenhouses) and natural water bodies.

127 Composite LANDSAT images from our study area were obtained from the periods of interest

128 (1990, 2000, 2008 and 2014) using the Code Editor of Google Earth Engine [35]. Results of the

129 digitation process were overlapped over the LULC official vector layers from the periods of

130 interest and further rasterized. Digitation, rasterization and overlapping analysis were conducting

131 in QGIS 3.10 [36].

132 For our LULC change analysis we used a modified categorization from MAE-MAGAP [31], we

133 combined level 1 and 2 official LULC taxonomy (S1Table). Briefly we aggregated all the

134 agricultural level 2 typologies into agricultural land, and as suggested by MAE-MAGAP [31],

135 we included pasture to this LULC class since in the highlands of Ecuador there is a system of

136 rotation from pasture to agricultural fields along the cropping cycles. In addition, because the

137 study area corresponds to the major center of floriculture production for the export market in

138 Ecuador [37,38], we added floriculture crop, as a separate typology from the agricultural land.

139 As a result, the identified LULC classes were 1) developed, 2) floriculture crop, 3) agricultural 
140 land, 4) planted forest, 5) shrubland and herbs, 6) native forest, 7) paramo and 8) water bodies

141 (S1 Table).

\section{Land Use and Cover changes}

143 Firstly, we mapped and estimated the land area occupied by each LULC class through time and

144 the percentage change $(\mathrm{C} \%)$ in each land-use class was calculated by dividing the area

145 difference between the latest and the base year of each class by the coverage area in the base year

146 and multiplying by 100 [24].

147 Then, LULC changes were estimated for three periods of analysis: for 1990-2000 (T1), 2000-

1482008 (T2) and 2008-2014 (T3). Furthermore, to analyze the succession of LULC classes in these

149 periods of analysis, we used discrete-time, finite-state, homogeneous (stationary) Markov chain

150 models, which have been widely used to model LULC changes [39-42]. The Markov Chain

151 probability Matrix was estimated, using the markovchain R-package [43] for five administrative

152 zones (at the parish level) and across four elevation bands. By applying a Markov chain model

153 for three periods of analysis to land use classes it is possible to observe conversions between

154 them when values are higher than 0.5$)$; in contrast the stability probability is observed when

155 higher values are compared between the same LULC class, representing the probability of

156 remaining in the same class in the consequent time period, given the present state of the class.

157 The spatial patterns of LULC change across administrative zones were obtained from an overlay

158 procedure of the LULC maps with the polygons of parishes from the studied Pedro Moncayo

159 county, which were downloaded from the official reference [44]. In the same way, to understand

160 the patterns of LULC change across elevation classes, first the National Digital Elevation Model

161 at a $30 \mathrm{~m}$ spatial resolution [45] was clipped to the study area, after that, the resulting image was

162 further reclassified according to elevation bands, with an interval of $500 \mathrm{~m}[46,47]$, resulting in

163 the following four elevation bands $<2300,2300-2800,2800-3300$, $>3300$ (Fig 1); these 
164 groupings take into consideration the mean medium of relief surface roughness, type of forests

165 and the presence of urban areas [46]. Finally, the LULC classification for each year was layered

166 over both (1) the reclassified elevation map, and the (2) reclassified administrative map. Spatial

167 data assimilation, processing and overlaying analysis were conducted in the R environment [48].

\section{Drivers of change}

169 To understand what predictors could explain the LULC dynamics we tested a set of five group of

170 variables that have previously been reported as possible drivers of change $[7,12]$ and were

171 described in the conceptual framework that interconnects: Driving forces - Pressure - State -

172 Benefits / Impacts- Response adopted by the European Environment Agency [25]; a scheme also

173 used by the Ministry of the Environment of Ecuador as a tool to guide the formulation and

174 adjustment of policies to foster biodiversity conservation in Ecuador [49]. Within this approach,

175 we compiled a dataset of 13 variables of LULCC ranging from (1) socio-economic, (2)

176 topography, (3) anthropic pressures to natural ecosystems, (4), climate and (6) governance

177 decisions toward landscape development (Table 1).

178 In order to increase the number of units of analysis within parishes, all these variables were

179 obtained at the spatial resolution of census area [50]. After all the spatial data assimilation,

180 processing and visualisation necessary to obtain the drivers at the spatial unit of analysis, we

181 carried out a reduction dimension procedure using Principal Component Analysis [51] of the

182 drivers of change to summarize the distinct variables within the grouping drivers, all these

183 procedures were completed using R software (version 3.2.3) [48]. Correlated variables were

184 screened for the total variation explained by the first principal axes, and used to remove

185 correlated variables [52]. Coordinates of the principal components that accounted for more than

$18660 \%$ of the variation were then used as explanatory variables in a subsequent statistical model. 


\begin{tabular}{|c|c|c|c|c|c|}
\hline Type & Name & Units & Description & $\begin{array}{l}\text { Spatial } \\
\text { resolution }\end{array}$ & Source \\
\hline \multirow{2}{*}{$\begin{array}{l}\text { Socio- } \\
\text { economic } \\
\text { driving forces }\end{array}$} & Education index & NA & $\begin{array}{l}\text { Change of a compounded index of } \\
\text { eight census indicators of education, } \\
\text { with parish breakdown, between years }\end{array}$ & Census areas & $\begin{array}{l}\text { Instituto Nacional de Estadísticas y } \\
\text { Censos [53] (1990 y 2001, 2010, 2014*) }\end{array}$ \\
\hline & $\begin{array}{l}\text { Index of economic } \\
\text { diversification of } \\
\text { employment }\end{array}$ & NA & $\begin{array}{l}\text { Change of index of economic } \\
\text { concentration of employment between } \\
\text { years of study }\end{array}$ & Census areas & $\begin{array}{l}\text { Instituto Nacional de Estadísticas y } \\
\text { Censos [53] (1990 y 2001, 2010) }\end{array}$ \\
\hline \multirow{2}{*}{$\begin{array}{l}\text { Pressure } \\
\text { drivers }\end{array}$} & Total population & $\begin{array}{l}\text { Number of } \\
\text { inhabitants }\end{array}$ & $\begin{array}{l}\text { Change of total population between } \\
\text { years of study }\end{array}$ & Census areas & $\begin{array}{l}\text { Instituto Nacional de Estadísticas y } \\
\text { Censos [53] (1990 y 2001, 2010) }\end{array}$ \\
\hline & $\begin{array}{l}\text { Distance to roads } \\
\text { Distance to nearest } \\
\text { cities }\end{array}$ & $\mathrm{km}$ & $\begin{array}{l}\text { Change of distance to roads or nearest } \\
\text { cities, between years of study }\end{array}$ & $30 \mathrm{~m}$ & $\begin{array}{l}\text { Cartography - Instituto Geográfico } \\
\text { Militar and digitation from Landsat } \\
\text { images }(1990,2000,2008)\end{array}$ \\
\hline \multirow{3}{*}{$\begin{array}{l}\text { Climate } \\
\text { factors }\end{array}$} & $\begin{array}{l}\text { Maximum } \\
\text { Temperature } \\
\text { Minimum } \\
\text { Temperature }\end{array}$ & ${ }^{\circ} \mathrm{C}$ & $\begin{array}{l}\text { Change of daily maximum air } \\
\text { temperatures at } 2 \text { metres averaged } \\
\text { over each month and summarized in a } \\
\text { year }\end{array}$ & $1 \mathrm{~km}$ & $\begin{array}{l}\text { Chelsa datasets tmax, tmin, prec }(1990, \\
2000,2008)[54,55]\end{array}$ \\
\hline & Precipitation & $\mathrm{mm}$ & $\begin{array}{l}\text { Change of monthly means of daily } \\
\text { forecast accumulations of total } \\
\text { precipitation at earth surface } \\
\text { summarized in a year }\end{array}$ & & \\
\hline & $\begin{array}{l}\text { Water availability by } \\
\text { Irrigation }\end{array}$ & NA & $\begin{array}{l}\text { Availability of water from the main } \\
\text { irrigation system }\end{array}$ & $30 \mathrm{~m}$ & digitation from Google images (2008) \\
\hline \multirow{3}{*}{$\begin{array}{l}\text { Ecological } \\
\text { context }\end{array}$} & Altitude & $\mathrm{m}$ & height in relation to sea level & & \multirow{3}{*}{$\begin{array}{l}\text { Digital Terrain Model (SRTM) - Instituto } \\
\text { Geográfico Militar }\end{array}$} \\
\hline & Aspect & degrees & $\begin{array}{l}\text { orientation of slope, measured } \\
\text { clockwise in degrees from } 0 \text { to } 360\end{array}$ & $30 \mathrm{~m}$ & \\
\hline & Slope & $\%$ & $\begin{array}{l}\text { Steepness or the degree of incline of a } \\
\text { surface }\end{array}$ & & \\
\hline $\begin{array}{l}\text { Production } \\
\text { development }\end{array}$ & Parrish typologies & NA & $\begin{array}{l}\text { Gradient of production development } \\
(1-5) \text { based on policy decisions across } \\
\text { administrative zones }\end{array}$ & parrish & $\begin{array}{l}\text { Land use development plan of Pedro } \\
\text { Moncayo county (2015) [26] }\end{array}$ \\
\hline
\end{tabular}




\section{Statistical analysis}

191 We synthesized and incorporated the different grouping drivers into a statistical model to

192 improve LULC predictions and inform decision making by carrying out multivariate analysis

193 using Generalized Additive Models (GAM). GAMs are an approach used extensively in

194 environmental modelling and provide great scope to model complex relationships between

195 covariates [56,57]. We used GAM regressions to elucidate two types of transitions in our study

196 area: 1) the probability of natural ecosystems loss, and 2) the probability to change towards

197 anthropic environments. The LULC trends evaluated as response variables within the first

198 approach were the probability of loss of native forest, paramo and shrubs and herbs;

199 complementary, the second approach tried to explain what drivers could cause the transitions

200 towards developed areas, floricultural crops and food crops pastures. We did not include

201 transitions toward planted forests because this LULC demonstrated to be very stable during the

202 periods of analysis. As explained in the previous section, the explanatory variables for each

203 GAM were the coordinates of the PCA that explained more of the $60 \%$ of the variation in the

204 multivariate matrix.

205 The computational methods for the GAM modelling were implemented from the cran repository

206 'mgcv' package [58], since in our study the response variable is a probability ranging from 0 to

207 1, we used the GAM family as a Beta Regression, as suggested by this type of data [59]. For the

208 smoothing basis function, we use the penalized cubic regression spline to lower computation cost

209 and avoid overfitting; the smoothing parameter estimation was restricted maximum likelihood

210 ('REML'), typically used for smooth components viewed as random effects [56]. After checking

211 the results of different models using distinct methods for selecting the number of knots (default,

212 cross validation and manual adjustments), we selected the more conservative models, setting the

213 number of knots in three to be flexible enough to allow the models to fit simple curve 
214 relationships and preventing spline curves with complex overfitting estimates, which would have

215 limited the interpretation ability from the ecological perspective. We presented the results of the

216 GAMs with Partial Dependence Plots (PDP) using the 'mgcv' R-package [58] to determine

217 which variable best explained the variation in LULC change [56].

\section{Results}

\section{Coverage area for each year}

220 Agricultural land was the most representative LULC type in the study area, followed by shrubs

221 and herbs (Fig 2). Both LULC types were very dynamic over the different periods of analysis,

222 agricultural land ranged from 35 to $50 \%$ of the total area, depending on the period of analysis

223 (Table 2), and shrubs and herbs varied from 16 to $28 \%$ of the total area, depending on the period

224 analyzed (Table 2).

225 Overall natural ecosystems, which are mainly represented by native forests and paramos,

226 decreased from 1990 to 2014 (Table 2), there was a 40\% and 16\% decrease of native forest and

227 paramo cover when compared the first and last periods of study (Table 2); but, by the last period

228 of study, areas of paramo still represent an important part (13\%) of the study territory. Natural

229 water bodies (lakes and rivers) showed high persistence over time (Table 2).

230 Developed areas and floricultural crops were continuously increasing over time, and although

231 they were poorly represented in the first period of analysis (less than $0.4 \%$ in 1990), by 2014

232 they represented almost 5\% of the study area (Table 2), demonstrating a 26 and 13 times fold of

233 increase from 1990 to 2014, respectively. 
237 Table 2. Changes in land cover classification in Pedro Moncayo county from 1990 to 2014

\begin{tabular}{|c|c|c|c|c|c|c|c|c|c|}
\hline \multirow[t]{2}{*}{$\begin{array}{l}\text { LULC } \\
\text { TYPE }\end{array}$} & \multicolumn{2}{|c|}{1990} & \multicolumn{2}{|c|}{2000} & \multicolumn{2}{|c|}{2008} & \multicolumn{2}{|c|}{2014} & $\begin{array}{l}2014- \\
1990\end{array}$ \\
\hline & $\mathrm{km}^{2}$ & $\%$ & $\mathrm{~km}^{2}$ & $\%$ & $\mathrm{~km}^{2}$ & $\%$ & $\mathrm{~km}^{2}$ & $\%$ & Change \\
\hline Developed & 0.58 & 0.17 & 4.72 & 1.39 & 9.61 & 2.84 & 15.54 & 4.60 & 2569.55 \\
\hline Floriculture crop & 1.19 & 0.35 & 9.44 & 2.79 & 14.06 & 4.16 & 16.75 & 4.95 & 1305.89 \\
\hline $\begin{array}{l}\text { Food crop and } \\
\text { pasture }\end{array}$ & 152.92 & 45.20 & 122.58 & 36.23 & 169.29 & 50.04 & 137.03 & 40.51 & -10.39 \\
\hline Planted forest & 44.16 & 13.05 & 38.56 & 11.40 & 37.35 & 11.04 & 38.24 & 11.30 & -13.42 \\
\hline Shrubs and Herbs & 73.33 & 21.68 & 94.74 & 28.00 & 53.40 & 15.78 & 77.75 & 22.98 & 6.02 \\
\hline Native forest & 12.96 & 3.83 & 15.11 & 4.47 & 11.29 & 3.34 & 7.77 & 2.30 & -40.03 \\
\hline Paramo & 50.62 & 14.96 & 50.60 & 14.96 & 40.73 & 12.04 & 42.51 & 12.57 & -16.03 \\
\hline Lake & 1.48 & 0.44 & 1.52 & 0.45 & 1.52 & 0.45 & 1.66 & 0.49 & 12.29 \\
\hline River & 1.04 & 0.31 & 1.06 & 0.31 & 1.04 & 0.31 & 1.04 & 0.31 & 0.09 \\
\hline Total & 338.29 & 100.00 & 338.33 & 100.00 & 338.29 & 100.00 & 338.29 & 100 & 0.00 \\
\hline
\end{tabular}

Landscape dynamics through time was not homogenous along the study area, instead it shows a geographic pattern (Fig 2). Expansion of developed areas and floriculture crops occurred mainly

241 in the southeastern part of the studied region (Fig 2). The greatest degree of loss in native forests

242 and paramos occurred in the northeast (Figs 2 and 3), where there is almost no paramo left due to

243 the expansion of agricultural land.

Fig 2. A. LULC maps of Pedro Moncayo county thoughout the periods of study (1990, 2000, 2008 and 2014). B. Land extent changes through time in the Pedro Moncayo county by administrative zones at the parish scale.

248 Fig 3. Transition probability of native ecosystems through time in Pedro Moncayo county, at the parish level

\section{Land-change dynamics through time}

\section{Transitions of native ecosystems}

253 In general, as expected the stability of native forests is decreasing through time in the entire

254 territory (Fig 3), with the exception of the western parish where the probability of remaining in

255 this LULC class increases through time probably due to agricultural land abandonment (Fig 3).

256 In contrast, areas located in the east tend to have lower values of stability through time and

257 higher probabilities to change to paramo and agricultural land; this pattern was more evident in 
the last period evaluated (2008-2014) (Fig 4). Additionally, this trend is more evident along

259 elevation bands; where native forests located above $3300 \mathrm{~m}$ showed a lower probability of remaining as forest along the years (Fig 4) and in the 2800-3300 altitudinal belt there is a high probability of converting native to planted forests, especially in the center of the territory (Fig 4).

Fig 4. Transition probability of native forests through time in Pedro Moncayo county, by altitudinal bands

263 at the parish level.

264

265 Furthermore, shrubs and herbs show variable change throughout the study period (Fig 3).

266 In the majority of administrative areas, the stability of shrubs and herbs decreased (from values

267 around 0.75 to values close to of 0.25$)$ in the second period of evaluation (2000-2008) and

268 increased again in the last period (2008-2014). Across all elevation belts, this LULC class tend to

269 follow a dynamic trend changing back and forth with the agricultural land; however, this pattern

270 was not observed in the eastern parish at the elevation belt of $2800-3300$, where the landscape

271 seems to have a high probability of remaining as agricultural land (S1 Fig).

272 In contrast, paramo is the most stable among all natural ecosystems evaluated, although a slight

273 decrease in stability was observed from values above 0.90 to around 0.75 in the second period of

274 analysis (2000-2008) (Fig 3), the probability of remaining in the same land use class increased

275 by the last period of analysis (2008-2014). Since this ecosystem is characteristic of highlands

276 (above $3000 \mathrm{~m}$ ) the transition probabilities were only observed for the two higher elevation belts

277 evaluated and their stability seems to be increasing in the administrative zone located in the

278 western part of the territory (S2 Fig).

\section{Transitions to anthropic environments}

281 Developed areas demonstrate a differential trend through time in the study area (Fig 5). In the

282 western areas of the territory (Fig 5) the stability of this LULC class decreased in the second 
283 period of evaluation (2000-2008) and significantly increased again in the last time period (2008-

284 2014), in contrast, the parishes located to the east exhibit a more stable probability of remaining

285 as developed areas through time probably due to the proximity of the larger towns (Fig 5). Since

286 the territory studied is in general a rural area, there is a dynamic trend towards converting

287 agricultural to urban areas, which follow a geographic pattern (Fig 5).

288 To the east and center of the study area, floriculture crops have not been fully established

289 because it tends to change toward Agricultural land (Fig 5); in contrast this LULC type located in

290 the eastern parishes is more stable with values around 0.75 throughout the period of study (Fig

$2915)$.

292 Agricultural land is a very stable land use class throughout the study period in the administrative

293 zones located in the center and eastern part of the study area with values ranging above 0.77 (Fig

294 5); the stability of this land use class in the west followed a dynamic trend through time: in the

295 first period of analysis (1990 -2000) it was lower than in the second period of analysis and it

296 increased again by the last period of analysis. In contrast, planted forests depict a very stable land

297 use trend thorough time across the territory, their probability of remaining in the same land use

298 class ranges from 0.6 to 0.90 (Fig 5).

299 Fig 5. Transition probability to anthropic environmets through time in Pedro Moncayo county, at the 300 parish level

\section{Drivers of change}

303 The drivers of change, which are mainly the result of a dimension reduction of distinct variables

304 organized in grouping drivers by PCA analysis, displayed different spatial distribution within the

305 study area (S3 and S4 Figs), depicting a territory with contrasting patterns. The details of the

306 spatio-temporal distribution of the drivers of change are presented in S3 and S4 Figs. 
Table 2 describes the results of the different LULC transitions studied and their main explanatory native forest loss model and the largest value (41.80\%) was for the agricultural expansion model.

312 Overall, the most relevant parameters explaining LUCC in the region were the ecological context

313 grouping driver (which incorporates elevation and slope), this grouping driver was highly

314 significant for the majority of the transitions studied $(\mathrm{p}<0.001$, Table 2$)$, with the exception of

315 the Shrub and Herbs expansion. In contrast, the climate grouping driver PC1 (which depicts

316 mostly the variation of precipitation and minimum temperature) was not significant in any model

$317(\mathrm{p}>0.05)$.

318 Table 2. Summary of the results of the General Additive Models to elucidate drivers of change for the six 319 LULC transition models in Pedro Moncayo county.

\begin{tabular}{|c|c|c|c|c|c|c|c|c|c|c|c|c|c|c|c|c|c|c|}
\hline \multirow[t]{2}{*}{ Drivers } & \multicolumn{3}{|c|}{ native forest loss } & \multicolumn{3}{|c|}{ paramo loss } & \multicolumn{3}{|c|}{ shrub loss } & \multicolumn{3}{|c|}{ urbanization } & \multicolumn{3}{|c|}{ Floriculture expansion } & \multicolumn{3}{|c|}{ Agriculture expansion } \\
\hline & $p$ value & chi sq & edf & $p$ value & chi sq & edf & $p$ value & chi sq & edf & $p$ value & chi sq & edf & $p$ value & chi sq & edf & $p$ value & chi sq & edf \\
\hline socioeconomic PC1 & 0.000 & 19.65 & 1.8 & 0.721 & 0.00 & $<1$ & 1.000 & 0.00 & $<1$ & 0.468 & 0.00 & $<1$ & 0.307 & 0.05 & $<1$ & 0.812 & 0.00 & $<1$ \\
\hline ecological context PC1 & 0.000 & 13.32 & 1.4 & 0.000 & 23.89 & 1.5 & 0.426 & 0.00 & $<1$ & 0.000 & 16.69 & 1.7 & 0.001 & 9.62 & 1.4 & 0.000 & 18.48 & 1.9 \\
\hline climate factors PC1 & 0.889 & 0.00 & 1.0 & 1.000 & 0.00 & $<1$ & 1.000 & 0.00 & $<1$ & 1.000 & 0.00 & $<1$ & 0.774 & 0.00 & $<1$ & 0.814 & 0.00 & $<1$ \\
\hline climate factors PC2 & 0.336 & 0.00 & $<1$ & 0.791 & 0.00 & $<1$ & 0.374 & 0.00 & $<1$ & 0.609 & 0.00 & $<1$ & 0.018 & 4.23 & $<1$ & 0.039 & 3.06 & $<1$ \\
\hline pressure drivers PC1 & 0.547 & 0.00 & $<1$ & 1.000 & 0.00 & $<1$ & 0.000 & 17.02 & 1.76 & 0.000 & 26.71 & 1.8 & 0.936 & 0.00 & $<1$ & 0.000 & 15.21 & 1.3 \\
\hline pressure drivers PC2 & 0.189 & 0.721 & $<1$ & 1.000 & 0.00 & $<1$ & 0.364 & 0.00 & $<1$ & 0.048 & 0.00 & 1.2 & 0.144 & 1.24 & $<1$ & 1.000 & 0.00 & $<1$ \\
\hline parrish gov & 0.507 & 0 & $<1$ & 0.118 & 1.46 & $<1$ & 0.000 & 25.53 & 1.53 & 0.386 & & $<1$ & 0.000 & 10.41 & 1.2 & 0.000 & 31.00 & 1.8 \\
\hline Deviance explained & $21.00 \%$ & & & $20.80 \%$ & & & $39.90 \%$ & & & $36.50 \%$ & & & $25.00 \%$ & & & $41.80 \%$ & & \\
\hline R-sq.(adj) & 0.22 & & & 0.15 & & & 0.29 & & & 0.30 & & & 0.21 & & & 0.33 & & \\
\hline
\end{tabular}

324 For the native forest loss model, the most important grouping drivers $(\mathrm{p}<0.001)$ were the

325 socioeconomic and the ecological context grouping drivers (Fig 6, Table 2). For instance,

326 paramo loss was only explained by the variation in elevation and slope (ecological context PC1)

327 (Table 2, S5 Fig). Figure 6 shows the GAM PDPs for the native forest loss model and indicates

328 that the probability of native forest loss increases as land aspect PC1 increases, in other words, 
when elevation and slope increases. In contrast, when the socioeconomic variables have low and high values the probability of forest loss increases, although the confidence interval for lower

331 values in the socioeconomic drivers has higher values.

332

333

334

335

336

337

338

339

340

341

342

343

344

345

346

347

349 parish level.

350 Variables leading to the highest change in the probability of transition to floriculture crops

351 comprise the ecological context grouping driver, the climate PC2, which includes water

352 irrigation and the development gradient across parishes. Floriculture crops increase as elevation

353 and slopes decrease. Complimentary, when more water is available through irrigation, the

354 probability of establishing floriculture crops increase (S9 Fig). 
356 For instance, the urbanization transition model was explained by ecological context and pressure

357 grouping drivers PC1 $(\mathrm{p}<0.001)$ (Table 2$)$. Urban transition probabilities decrease significantly

$358(\mathrm{p}<0.001)$ with altitude and slope, it also significantly decrease $(\mathrm{p}<0.001)$ with the distance to the

359 city centers (pressure PC1), and with higher values of total population change (pressure - PC2)

360 (S10 Fig).

\section{Discussion}

362 Even though major milestones for landscape transformation occurred centuries ago in the

363 Ecuadorian highlands [6,60-62], our study demonstrates that, at present, a combination of

364 environmental variables and human induced factors still have an impact on an even LULC

365 transformation as reported for other mountainous landscapes of Latin America [7,9,10,12]. The

366 studied area depicts a rural Andean landscape dominated by an agricultural matrix which

367 contains important areas of shrubland and paramo, accompanied by patches of remaining native

368 forest, which is consistent with other current landscapes in the Tropical Andes [7,12,24,62].

369 We also found a geographic pattern of LULC transition across the study area; we report a clear

370 deforestation pattern of native montane forests located below 3300 m.a.s.1, an unexpected high

371 stability pattern of paramos for the majority of the studied territory and a dynamic transition

372 between agricultural land and shrubland was found; in addition, we found an exponential

373 increase in urban land and floriculture crops in the eastern part of the territory. This result is

374 striking because of the small spatial scale where the changes occur; our study area encompasses

375 only $334 \mathrm{~km}^{2}$ compared to other landscapes studied in Central Ecuador [62], in the Peruvian

376 Puna [24] or in Colombia [12], where the land extent are 10, 120 and 800 times larger than our

377 studied territory. 
378 We estimated a paramo loss of 16\% from 1990 to 2014 in Pedro Moncayo county (Table 1), this

379 result is consistent with the findings of loss (13\%) in a nearby territory [63]. Although most of

380 the studied territory depicted a high stability pattern of paramo, as also described for a highland

381 landscape of central Ecuador (Ross et al 2017), our results also demonstrated a hotspot of

382 paramo conversion to agricultural land concentrated in the northeast. In contrast, our results are

383 strikingly different with the land cover patterns observed in other paramos in the region, where a

384 more widespread agricultural use of paramo was observed [64-66]. Although, another common

385 transition reported for paramos in the Ecuadorian mountains is to exotic timber plantations [18],

386 this trend was not apparent for our studied territory.

387 We found a 40\% montane forest loss from 1990 to 2014, and the Markov chain model

388 demonstrated a very low probability of persistence of this ecosystem in the majority of Pedro

389 Moncayo county (Figs 2 and 4); this is consistent with the general trend of deforestation and

390 degradation of mountain forests in the Tropical Andes mainly explained by agricultural

391 expansion [67]. We also found that the highest chances of loss occur in the altitudinal band of

3922800 to 3300 (Fig 3); these findings are in accordance with the findings described for other

393 representative highlands in central Ecuador [62]; however, LULC change studies carried out in

394 more isolated landscapes of central and southern Ecuador reported deforestation hotspot for

395 lowland montane forests and afforestation transition in upper altitudinal areas $[10,68]$;

396 additionally, higher rates of deforestation was also observed in lowland forest of Colombia, in

397 the Napo region along the Ecuadorean border [12].

398 Mountain forests are considered one of the most threatened forests in the tropics [69,70], which

399 are also highlighted as a global priority for conservation due to their great biodiversity and high 
400 level of endemism [71], and its vital role in the provisioning of different ecosystem services in

401 the region [72,73]. However, if the trends demonstrated by the Markov model are maintained for

402 this territory, there is a high probability that the remnant montane forests will be permanently

403 lost in a few years, posing a greater threat to the already vulnerable biodiversity [69] and limiting

404 the capacity of these ecosystems to provide services in the county, such as provisioning and

405 regulating of freshwater, "wild foods" and many other non-timber forest products [22,74], as

406 described for other latitudes [75-77].

407 Along with this deforestation trend, we observed a dynamic and opposite transition between

408 agriculture areas and shrubland, this pattern was more evident for the parishes located in the

409 center of Pedro Moncayo county and along the elevation bands between 2300 to 3300 m.a.s.l.

410 This pattern could demonstrate a gain of secondary vegetation, probably due to a temporal

411 abandonment of agricultural areas, follow by a net gain of agricultural land which has been

412 observed in other Andean systems of Colombia [12] and Central America [78].

413 We found that urban areas are dramatically increasing in the eastern part of the territory (Fig 1,

414 Table 1); we reported a 25-fold increase in urban cover from 1990 to 2014. This pattern is

415 following the global trend of urban expansion [79], but the rate of extension is even faster than

416 what has been reported for many cities around the world [80] and in small urban centers [81]

417 [79]. In our study, higher probabilities of urban land expansion were explained by increases in

418 population, proximity to urban centers and occurred at lower elevations and slopes in previous

419 crop land. This pattern has been observed in other regions of South America, where urban

420 expansion is taking place largely on agricultural land [79], a zone characterized by areas of lower 
421 altitude and slope, which in the Andean zones correspond to the more fertile valleys between

422 mountains.

423 Another interesting finding was the exponential expansion of flower cultivation cover reported

424 for Pedro Moncayo county (Table 1, Fig 2). We described a 13-fold increase in total land area of

425 greenhouse floriculture from 1990 to 2014 (Table 1); this expansion was observed primarily in

426 the eastern parishes of the territory (Figs 1-3), which are located contiguous to Cayambe county,

427 another center for the development of this activity in Ecuador [63]. This region, situated in

428 Pichincha Province, has an equatorial location and has optimal sunlight conditions (long hours

429 of daylight) and an ideal highland climate (abundant sunshine, warm days and cool nights) which

430 make it possible to produce some of the highest quality flowers in the world [37,38].

431 Our analysis suggests that in addition to the ecological context variables, another driver that

432 explain the floriculture expansion pattern is the water availability by irrigation, depicted by the

433 geographic pattern of irrigation in the lower eastern part of the studied territory, creating a better

434 environment for growing crops which would have been limited by natural precipitation as

435 demonstrated by [82] to increase yield in many crops. This irrigation canal transports water from

436 the glacier of a snow-capped mountain located in a contiguous territory, corresponding to the

437 neighboring county (Cayambe), and reaches only to the center of the territory and distributes

438 water to lower elevations, therefore only the area situated to south-east receives water for

439 irrigation.

440 We found that ecological context variables (elevation and slope) are the most important drivers

441 for all LULC transitions. For instance, native ecosystems transitions (including the models to

442 explain loss of native forest and paramo) and agricultural expansion were both significantly

443 related to changes in elevation and slope, in such a way that the probability of native ecosystems 
444 loss and the probability of agriculture expansion increase with elevation and slope, until they

445 reach a certain value where they level off (native forest and paramo models) and even decrease

446 (shrubs and herbs loss and agricultural expansion models). These complementary trends suggest

447 that the major pressure for native ecosystems in this highland system of northern Ecuador is still

448 the expansion upwards of the agricultural-livestock frontier as also found in other Andean

449 landscapes [12,62]. In addition, the expansion of urban areas and floriculture crops in the

450 previous agricultural land, located at lower elevations of the eastern part of the territory could

451 also make pressure for an expansion of the agricultural frontier in highland areas. Even though,

452 we did not find evidence that climatic variation explained the LULC transitions, the effect of

453 climate change could be stronger in a nearby future due to the extreme events predicted in the

454 Tropical Andes [83], affecting the capacity of highland ecosystems to keep providing key goods

455 and services to people [84].

456 The trend of native ecosystem loss associated to higher elevation and slope observed in this

457 landscape of northern Ecuador could be attributed by its past patterns of land use as summarized

458 by $[3,85]$; since the most striking transformation and loss of native ecosystems in Andean

459 landscapes occurred centuries ago and it was even expanded in the mid-twenty century by the

460 agrarian reform, current native ecosystems are only the remnant patches, localized at higher

461 elevations and slopes [22]. However, the leveling off and the further decrease in the probability

462 of native forest loss at higher values of topographic variables, could be explained by

463 conservation measures adopted to restrict human activities in the upper mountain belt, like

464 establishing protected areas $[3,22,62]$ or implementing national or local policies to limit

465 agricultural expansion [4] that have prevented the loss of high mountain ecosystems in other

466 Andean regions $[7,19]$. 
467 Paramos and other high-elevation ecosystems (pristine native forest patches), which are

468 ecosystems situated above $3500 \mathrm{~m}$ in the northern highlands of Ecuador, are currently more

469 valued by its importance for provisioning critical ecosystem services and, thus, in Ecuador have

470 received special protection measures at the national [86,87] and local level [88].

471 Although, other studies [7,12,24] have also found that environmental variables such as

472 topography were better predictors of woody vegetation change, arguing that these variables place

473 physical limits on the types of land-use practices that are feasible in a region, the trends were

474 different from those observed in our study in that these authors found that deforestation occurred

475 in the lowlands, which are more appropriate for large-scale mechanized agriculture [7,12,24].

476 However, the dynamic transition trend between agricultural land and shrubland observed in our

477 study, could be attributed to natural reforestation succession at high elevations (e.g., cooler

478 temperatures, steeper slopes), which is consistent with other studies [7,68]. In our study, this

479 pattern was also associated to variation in population change, which could be attributed to

480 population migration dynamics within the territory; movements of farmers from higher

481 mountainous zones to urban concentrated areas have been largely documented in different

482 regions of Latin America and are the drivers associated to natural reforestation in higher

483 elevations due to agricultural land abandonment [19]. This finding is consistent with the local

484 demography dynamics, where urban population has tripled from 1990 to 2010 (from 3000 to

48510000 inhabitants) while rural population has doubled (12000 to 23000 inhabitants) in the same

486 period [26].

487 In many places where this landscape transition was reported it has facilitated ecosystem recovery

488 in the highlands, likewise this has allowed maintaining the provision of ecosystem services for a

489 growing urban population [19]. The dynamic conversion from agricultural land to shrubland in 
some highland areas of this landscape, explained by rural-urban migration, is consistent with the

491 "Forest Transition Model” proposed by Mather [89], however in our study area the pattern is

492 uneven, for instance native forests are decreasing in some areas, while shrubland is expanding in

493 other areas, picturing a process of ecological succession before a fully recovered forest occurred.

494 Maintaining and increasing native ecosystems in higher elevations and expanding urban and

495 agriculture areas in the lowland and valleys raise new opportunities and challenges for

496 conservation; however, the consequences of these spatial transitions have not been studied in

497 depth [19].

498 We have considered a comprehensive set of factors characterizing landscape conversion

499 dynamics, however some limitations concerning the scope of the drivers used for this analysis

500 should be considered. The underlying driving forces affecting land-use transformations could

501 also be attributed by production support policies geared toward internal market and exports

$502[21,62]$, which were not included in our analysis. For instance, other studies suggest that the

503 greenhouse floriculture expansion initiated in the 1990s was partly in response to favorable trade

504 agreements but also due to diffusion of technologies from multiple sources and local

505 entrepreneurship [38]. Flower cultivation is a land- and labor-intensive activity with high land

506 productivity (that is, high market value of output per hectare) [37]. However, the gains in income

507 have surely been offset by growing health and environmental problems posed by the intensive

508 use of pesticides in flower cultivation [37].

509 All indications suggest that flower exports will continue to play a major and probably increasing

510 role in Ecuador's economy [37]; in fact, it is steadily expanding and it is causing land use

511 changes in the territory; for instance, former important and traditional lands dedicated to

512 livestock and food crop production, located in areas with aptitude to agricultural production and 
513 with access to irrigation systems have been transformed into green houses for flower cultivation,

514 posing a the trade-offs between agricultural production and environmental concerns, including

515 the asserted need for global land use expansion, and the issues of rural livelihoods and food

516 security [30].

517 The assessment of local and regional patterns of current land use and past land cover conversion

518 is the first step in developing sound land management plans that could prevent broad scale,

519 irreversible ecosystem degradation. This characterization of landscape patterns through time and

520 the analysis of their proximate drivers of landscape change enhance our understanding of how

521 landscape pattern might influence ecosystem services [90] and point out that research and

522 landscape management, zonation and ecological recovery/ restoration should become better

523 integrated into land-use policy and conservation agendas at the local level to balance the multiple

524 needs and benefits from Ecosystems of a growing population in a rural landscape of northern

525 Ecuador [91].

\section{Acknowledgments}

527 Thanks to the staff of the National Institute of Statistics and Census for sending the census

528 cartography databases not available on the web page and for their advice in interpreting the

529 coding of the databases. Thanks to Phoebe Lehmann Zarnetske for her sound suggestions on the

530 available climate databases. And last but not least, thanks to the students of the School of

531 Biological Sciences of the Central University who helped to collect information, especially

532 Genesis Granja who directly supported in obtaining geospatial data related to the drivers of

533 change.

\section{Author Contributions}

535 Conceptualization: Paulina Guarderas, Franz Smith, Marc Dufrene. 
Data curation: Paulina Guarderas.

537 Formal analysis: Paulina Guarderas, Franz Smith.

538 Funding acquisition: Paulina Guarderas, Marc Dufrene.

539 Investigation: Paulina Guarderas.

540 Methodology: Paulina Guarderas, Franz Smith.

541 Project administration: Paulina Guarderas.

542 Resources: Paulina Guarderas, Franz Smith.

543 Supervision: Marc Dufrene.

544 Validation: Paulina Guarderas, Franz Smith, Marc Dufrene.

545 Visualization: Paulina Guarderas, Franz Smith.

546 Writing - Paulina Guarderas.

547 Writing - review \& editing: Paulina Guarderas, Franz Smith, Marc Dufrene.

\section{References}

549

550

551

552

553

554

555

556

557

558

559

560

561

562

563

564

565

566

567

568

569

570

571

572

573

574

575

576

577

578

579

580

581

582

1. Körner C, Ohsawa M, Spehn E, Berge E, Bugmann H, Groombridge B, et al. Mountain systems. In: Hassan R, Scholes R, Ash N, editors. Ecosystems and human well-being: current state and trends,. volume 1. Washington DC,: Island Press; 2005. p. 683-716.

2. Payne D, Spehn EM, Snethlage M, Fischer M. Opportunities for research on mountain biodiversity under global change. Curr Opin Environ Sustain [Internet]. 2017;29:40-7. Available from: http://dx.doi.org/10.1016/j.cosust.2017.11.001

3. Young KR. Andean land use and biodiversity: Humanized landscapes in a time of change. Ann Missouri Bot Gard. 2009;96(3):492-507.

4. Peters MK, Hemp A, Appelhans T, Becker JN, Behler C, Classen A, et al. Climate-land-use interactions shape tropical mountain biodiversity and ecosystem functions. Nature. 2019;568(7750):88-92.

5. Gradstein SR, Homeier J, Gansert D. The Tropical Mountain Forest Patterns and Processes in a Biodiversity Hotspot. Biodiversi. Gradstein SR, Homeier J, Gansert D, editors. Vol. Biodiversi, Tropical Mountain Forest: Patterns and Processes in a Biodiversity Hotspot. Göttingen: Göttingen Centre for Biodiversity and Ecology; 2008. 35-50 p.

6. Sarmiento FO. Anthropogenic change in the landscapes of highland Ecuador. Geogr Rev. 2002;92(2):213-34.

7. Aide TM, Clark ML, Grau HR, López-Carr D, Levy MA, Redo D, et al. Deforestation and Reforestation of Latin America and the Caribbean (2001-2010). Biotropica. 2013;45(2):262-71.

8. Young KR. Ecology of land cover change in glaciated tropical mountains. Rev Peru Biol. 2014;21(3):259-70.

9. Madrigal-Martínez S, Miralles i García JL. Land-change dynamics and ecosystem service trends across the central high-Andean Puna. Sci Rep. 2019;9(1):1-12.

10. Gaglio M, Aschonitis VG, Mancuso MM, Puig JPR, Moscoso F, Castaldelli G, et al. Changes in land use and ecosystem services in tropical forest areas: A case study in Andes mountains of Ecuador. Int J Biodivers Sci Ecosyst Serv Manag [Internet]. 2017;13(1):264-79. Available from: https://doi.org/10.1080/21513732.2017.1345980

11. Young KR. Causality of Current Environmental Change in Tropical Landscapes. Geogr Compass. 2007;1(6):1299-314.

12. Rodríguez Eraso N, Armenteras-Pascual D, Alumbreros JR. Land use and land cover change in the Colombian Andes: Dynamics and future scenarios. J Land Use Sci. 2013;8(2):154-74.

13. Lambin EF, Geist HJ, Lepers E. Dynamics of land-use and land-cover change in tropical regions. Annu Rev Environ Resour. 2003;28:205-41. 
14. Nelson GC, Bennett E, Berhe AA, Cassman K, DeFries R, Dietz T, et al. Anthropogenic drivers of ecosystem change: An overview. Ecol Soc. 2006;11(2).

15. Wilson SJ, Coomes OT, Dallaire CO. The 'ecosystem service scarcity path' to forest recovery: a

local forest transition in the Ecuadorian Andes. Reg Environ Chang. 2019;19(8):2437-51.

16. Millennium Ecosystem Assessment. Ecosystems and Human Well Being [Internet]. Washington, DC.; 2005. Available from:

http://www.who.int/entity/globalchange/ecosystems/ecosys.pdf\%5Cnhttp://chapter.ser.org/europe/ files/2012/08/Harris.pdf

17. Lambin EF, Turner BL, Geist HJ, Agbola SB, Angelsen A, Bruce JW, et al. The causes of landuse and land-cover change: Moving beyond the myths. Glob Environ Chang. 2001;11(4):261-9.

18. Farley KA. Grasslands to Tree Plantations: Forest Transition in the Andes of Ecuador. Ann Assoc Am Geogr. 2007;97(4):755-71.

19. Grau HR, Aide M. Globalization and Land-Use Transitions in Latin America. Ecol Soc 13(2). 2008;113(2):16.

20. Rocha JM. Agricultural Intensification, Market Participation, and Household Demography in the Peruvian Andes. Hum Ecol. 2011;39(5):555-68.

21. Geist HJ, Lambin EF. Proximate causes and underlying driving forces of tropical deforestation. Bioscience. 2002;52(2):143-50.

22. Brandt JS, Townsend PA. Land use - Land cover conversion, regeneration and degradation in the high elevation Bolivian Andes. Landsc Ecol. 2006;21(4):607-23.

23. Hosonuma N, Herold M, De Sy V, De Fries RS, Brockhaus M, Verchot L, et al. An assessment of deforestation and forest degradation drivers in developing countries. Environ Res Lett. 2012;7(4).

24. Madrigal-Martínez S, Miralles i García JL. Land-change dynamics and ecosystem service trends across the central high-Andean Puna. Sci Rep. 2019;9(1):1-12.

25. Kristensen P. The DPSIR Framework. In: Workshop on a comprehensive / detailed assessment of the vulnerability of water resources to environmental change in Africa using river basin approach. Nairobi, Kenya: UNEP Headquarters; 2004.

26. GAD PM. Plan de Ordenamiento y Desarrollo Cantonal Pedro Moncayo [Internet]. 2015. p. 138. Available from: http://www.pedromoncayo.gob.ec/documentos/ord2015/PDOT.pdf

27. Ruiz S. Manejo Adaptativo de Riesgos y Vulnerabilidad en la Zona Lacustre de Mojanda. 2017.

28. De Noni G, Viennot M, Trujillo G. Chapter 13 Agricultural erosion in the Ecuadorian Andes. In: FAO Soils Bulletin. 1996.

29. Cáceres-Arteaga N, Ayala-Campaña O, Rosero-Vaca D, D. Lane KM. ¿Que nos depara el futuro? Análisis climático histórico y proyección de escenarios climáticos futuros para el cantón andino de Pedro Moncayo, Ecuador. Rev Geográfica América Cent. 2018;3(61E):297-318.

30. Gobierno Autonomo Descentralizado Pedro Moncayo. Plan De Ordenamiento Y Desarrollo Turistico. 2015.

31. MAE, MAGAP. Protocolo metodológico para la elaboración del mapa de cobertura y uso de la tierra del Ecuador Continental. Ministerio del Ambiente del Ecuador y Ministerio de Agricultura, Ganadería, Acuacultura y Pesca. 2015.

32. García-Llamas P, Geijzendorffer IR, García-Nieto AP, Calvo L, Suárez-Seoane S, Cramer W. Impact of land cover change on ecosystem service supply in mountain systems: a case study in the Cantabrian Mountains (NW of Spain). Reg Environ Chang. 2019;19(2):529-42.

33. Kroll F, Müller F, Haase D, Fohrer N. Rural-urban gradient analysis of ecosystem services supply and demand dynamics. Land use policy [Internet]. 2012;29(3):521-35. Available from: http://dx.doi.org/10.1016/j.landusepol.2011.07.008

34. Sreedhar Y, Nagaraju A, Murali Krishna G. An Appraisal of Land Use/Land Cover Change Scenario of Tummalapalle, Cuddapah Region, India-A Remote Sensing and GIS Perspective. Adv Remote Sens. 2016;05(04):232-45.

35. Gorelick N, Hancher M, Dixon M, Ilyushchenko S, Thau D, Moore R. Google Earth Engine: Planetary-scale geospatial analysis for everyone. Remote Sens Environ [Internet]. 
634

635

636

637

638

639

640

641

642

643

644

645

646

647

648

649

650

651

652

653

654

655

656

657

658

659

660

661

662

663

664

665

666

667

668

669

670

671

672

673

674

675

676

677

678

679

680

681

682

683

684
2017;202(2016):18-27. Available from: http://dx.doi.org/10.1016/j.rse.2017.06.031

36. QGIS Development Team. QGIS (Version 3.1.2A-Coruna) [Internet]. Open Source Geospatial Foundation Project. [cited 2019 Dec 1]. Available from: https://qgis.org/en/site/.

37. Sawers L. Sustainable Floriculture in Ecuador. 2005.

38. Knapp G. Mountain Agriculture for Global Markets: The Case of Greenhouse Floriculture in Ecuador. Ann Am Assoc Geogr. 2017;107(2):511-9.

39. Guan D, Gao W, Watari K, Fukahori H. Land use change of Kitakyushu based on landscape ecology and Markov model. J Geogr Sci. 2008;18(4):455-68.

40. Zhang B, Li S, Jia X, Gao L, Peng M. Adaptive Markov random field approach for classification of hyperspectral imagery. IEEE Geosci Remote Sens Lett. 2011;8(5):973-7.

41. Kumar S, Radhakrishnan N, Mathew S. Land use change modelling using a Markov model and remote sensing. Geomatics, Nat Hazards Risk [Internet]. 2014;5(2):145-56. Available from: http://dx.doi.org/10.1080/19475705.2013.795502

42. Cheng L, Xia N, Jiang P, Zhong L, Pian Y, Duan Y, et al. Analysis of farmland fragmentation in China Modernization Demonstration Zone since " Reform and Openness": A case study of South Jiangsu Province. Sci Rep [Internet]. 2015;5(May):1-11. Available from:

http://dx.doi.org/10.1038/srep11797

43. Spedicato G. Discrete Time Markov Chains with R. R package version 0.6.9.7 [Internet]. The R Journal. 2017 [cited 2019 Jan 5]. Available from: https://journal.r-project.org/archive/2017/RJ2017-036/index.html.

44. INEC - Instituto Nacional de Estadísticas y Censos. Clasificador Geográfico Estadístico - DPA [Internet]. Available from: https://www.ecuadorencifras.gob.ec/clasificador-geograficoestadistico-dpa/

45. Rurales SN de I de tierras e infraestructura tecnológica. Centro Geomático Virtual [Internet]. Available from: http://www.sigtierras.gob.ec/descargas/

46. Meybeck M, Green P, Vörösmarty C. A new typology for mountains and other relief classes: An application to global continental water resources and population distribution. Mt Res Dev. 2001;21(1):34-45.

47. Aik DHJ, Ismail MH, Muharam FM, Alias MA. Evaluating the impacts of land use/land cover changes across topography against land surface temperature in Cameron Highlands. PLoS One [Internet]. 2021;16(5 May):1-26. Available from: http://dx.doi.org/10.1371/journal.pone.0252111

48. R Core Team. R: A language and environment for statistical computing. Vienna, Austria.: R Foundation for Statistical Computin; 2019.

49. Larrea C, Cuesta F, López A, Greene N, Iturralde P, Maldonado G, et al., editors. Propuesta de indicadores nacionales de biodiversidad y su Plan de Acción 2015-2020. Quito, Ecuador: AE, CONDESAN, GIZ, PNUD-FMAM, USAB.; 2015.

50. Valle C. Reseña Histórica de la Cartografía en el Instituto Nacional de Estadística y Censos [Internet]. 2015. Available from: https://www.ecuadorencifras.gob.ec/libros-metodologicos-inec/

51. Dormann CF, Elith J, Bacher S, Buchmann C, Carl G, Carré G, et al. Collinearity: A review of methods to deal with it and a simulation study evaluating their performance. Ecography (Cop). 2013;36(1):27-46.

52. Clark M. General Additive Models [Internet]. 2019 [cited 2021 May 2]. Available from: https://mclark.github.io/generalized-additive-models/

53. INEC (Instituto Nacional de Estadísticas y Censos). Base de Datos - Censo de Población y Vivienda [Internet]. 2020 [cited 2020 Jul 1]. Available from:

https://www.ecuadorencifras.gob.ec/base-de-datos-censo-de-poblacion-y-vivienda/

54. Karger DN, Conrad O, Böhner J, Kawohl T, Kreft H, Soria-Auza RW, et al. Climatologies at high resolution for the Earth land surface areas. Sci Data. 2017;4 170122.

55. D.N. K, Conrad O, Böhner J, Kawohl T, Kreft H, Soria-Auza RW, et al. Data from: Climatologies at high resolution for the earth's land surface areas.

56. Barton NA, Farewell TS, Hallett SH. Using generalized additive models to investigate the 
environmental effects on pipe failure in clean water networks. npj Clean Water [Internet]. 2020;3(1):20-2. Available from: http://dx.doi.org/10.1038/s41545-020-0077-3

57. Wood S. Generalized Additive Models: An Introduction with R. 2nd ed. CRC Press; 2017.

58. Hastie T. Generalized Additive Models (gam). CRAN. 2020.

59. Ferrari S, Cribari-Neto F. Journal of Applied Statistics. J Appl Stat. 2004;31(7):799-815.

60. DELER JP, GOMEZ N, PORTAIS M. EL MANEJO DEL ESPACIO EN EL. ECUADOR. ETAPAS CLAVES. GEOGRAFIA BÁSICA DEL ECUADOR. Tomo II. Quito: Centro Ecuatoriano De Investigación Geográfica; 1983. 239 p.

61. Halliday A, Glaser M. Management Perspective On Social Ecological Systems. Res Hum Ecol. 2011;18(1):1-18.

62. Ross C, Fildes S, Millington AC. Land-use and land-cover change in the páramo of South-Central Ecuador, 1979-2014. Land. 2017;6(3).

63. Wigmore $\mathrm{O}$, Gao J. Spatiotemporal dynamics of a páramo ecosystem in the northern Ecuadorian Andes 1988-2007. J Mt Sci. 2014;11(3):708-16.

64. De S, Andes L, Del U, Charles E, Crissman C. La Agricultura En Los P Aramos: Estrategias Para El [Internet]. Lima; 2003. Available from:

http://condesan.org/mtnforum/sites/default/files/publication/files/cds01_agricultra_en_paramos_opt.pdf

65. Camacho M. Los Páramos Ecuatorianos : Caracterización Y Consideraciones Para Su Conservación Y. An la Univ Cent del Ecuador 372. 2013;76-92.

66. Garavito L. Los páramos en Colombia, un ecosistema en riesgo. Ingeniare, Univ Libr [Internet]. 2015;(19):127-36. Available from: http://www.unilibrebaq.edu.co/ojsinvestigacion/index.php/ingeniare/article/view/704

67. Tejedor Garavito N, Álvarez E, Arango Caro S, Araujo Murakami A, Blundo C, Boza Espinoza TE, et al. Evaluación del estado de conservación de los bosques montanos en los Andes tropicales. Ecosistemas. 2012;21(1-2):148-66.

68. Tapia-Armijos MF, Homeier J, Espinosa CI, Leuschner C, De La Cruz M. Deforestation and forest fragmentation in south Ecuador since the 1970s - Losing a hotspot of biodiversity. PLoS One. 2015;10(9):1-18.

69. Ataroff M. Selvas y bosques de montaña. In: Aguilera M, Azócar A, González-Jiménez E, editors. Biodiversidad en Venezuela. Tomo II. Caracas,: FONACIT-Fundación Polar; 2003. p. 762-810.

70. Mosandl R, Günter S. Sustainable management of tropical mountain forests in Ecuador. In: Gradstein SR, Homeier J, Gansert D, editors. The Tropical Mountain Forest Patterns and Processes in a Biodiversity Hotspot. Biodiversi. Göttingen: Göttingen Centre for Biodiversity and Ecology; 2008. p. 177-94.

71. Penningtona RT, Lavin M, Särkinen T, Lewis GP, Klitgaard BB, Hughes CE. Contrasting plant diversification histories within the Andean biodiversity hotspot. Proc Natl Acad Sci U S A. 2010;107(31):13783-7.

72. Anderson EP, Marengo J, Villalba R, Halloy S, Young B, Cordero D, et al. Consequences of climate change for ecosystems and ecosystem services in the tropical Andes. En: Clim. In: Herzog SK, Martínez R, Jørgensen PM, Tiessen H, editors. Climate change and biodiversity in the tropical Andes. Inter-American Institute for Global Change Research (IAI) and Scientific Committee on Problems of the Environment (SCOPE); 2011. p. 1-18.

73. Balvanera P. Los servicios ecosistémicos que ofrecen los bosques tropicales. Ecosistemas. 2012;21(1-2):136-47.

74. Westphal C, Bommarco R, Carré G, Lamborn E, Morison M, Petanidou T, et al. Measuring bee diversity in different European habitats and biogeographic regions. Ecol Monogr. 2008;78(4):65371.

75. Costanza R, de Groot R, Sutton P, van der Ploeg S, Anderson SJ, Kubiszewski I, et al. Changes in the global value of ecosystem services. Glob Environ Chang [Internet]. 2014;26(1):152-8.

Available from: http://dx.doi.org/10.1016/j.gloenvcha.2014.04.002 
76. Lawler JJ, Lewis DJ, Nelson E, Plantinga AJ, Polasky S, Withey JC. Projected land-use change impacts on ecosystem services in the United States. Proc Natl Acad Sci U S A. 2014;111(20):7492-7497|.

77. Millennium Ecosystem Assesment. Ecosystems and Human Well-being [Internet]. Vol. 5, Ecosystems. 2005. 1-155 p. Available from: http://www.who.int/entity/globalchange/ecosystems/ecosys.pdf\%5Cnhttp://www.loc.gov/catdir/to

\section{Supporting information}

778 S1 Figure. Transition probability of paramo through time in Pedro Moncayo county, by altitudinal

\section{9 bands at the parish level}


782 S3 Fig. Spatial distribution of each grouping driver for the first period of analysis. Each map represents the

783 PC1 from the Principal Component Analysis carried out for each grouping driver of change from the period

7841 (1990 and 2000).

785 S4 Fig. Spatial distribution of each grouping driver for the second period of analysis. Each map represents

786 the PC1 from the Principal Component Analysis carried out for each grouping driver of change from the period 2

787 (2000 and 1990).

788 S5 Fig. Generalized additive model partial dependence plots for forest paramo loss. Each

789 plot shows a covariate and their partial dependence on probability of native forest loss in the

790 context of the model. The $\mathrm{y}$ axis shows the mean of the probability of native forest loss and the $\mathrm{x}$

791 axis the covariate interval. The gray area represents the $95 \%$ confidence interval.

792 S6 Fig. Generalized additive model partial dependence plots for shrubland loss. Each plot

793 shows a covariate and their partial dependence on probability of native forest $\ln$ the context of

794 the model. The $\mathrm{y}$ axis shows the mean of the probability of native forest loss and the $\mathrm{x}$ axis the

795 covariate interval. The gray area represents the 95\% confidence interval.

796 S7 Fig. Generalized additive model partial dependence plots for agricultural transition.

797 Each plot shows a covariate and their partial dependence on probability of native forest $\ln$ the

798 context of the model. The $\mathrm{y}$ axis shows the mean of the probability of native forest loss and the $\mathrm{x}$

799 axis the covariate interval. The gray area represents the $95 \%$ confidence interval.

800 S8 Fig. Generalized additive model partial dependence plots for floriculture transition.

801 Each plot shows a covariate and their partial dependence on probability of native forest $\ln$ the

802 context of the model. The $\mathrm{y}$ axis shows the mean of the probability of native forest loss and the $\mathrm{x}$

803 axis the covariate interval. The gray area represents the $95 \%$ confidence interval.

804 S9 Fig. Generalized additive model partial dependence plots for urban transition. Each plot

805 shows a covariate and their partial dependence on probability of native forest ln the context of 
806 the model. The $\mathrm{y}$ axis shows the mean of the probability of native forest loss and the $\mathrm{x}$ axis the

807 covariate interval. The gray area represents the $95 \%$ confidence interval.

808

809 S1 Table. Land Use Land Cover classification scheme used to assess LULC change

810 analysis [31] 
bioRxiv preprint doi: https://doi.org/10.1101/2021.11.05.467450; this version posted November 5, 2021. The copyright holder for this preprint (which was not certified by peer review) is the author/funder, who has granted bioRxiv a license to display the preprint in perpetuity. It is made available under aCC-BY 4.0 International license. 


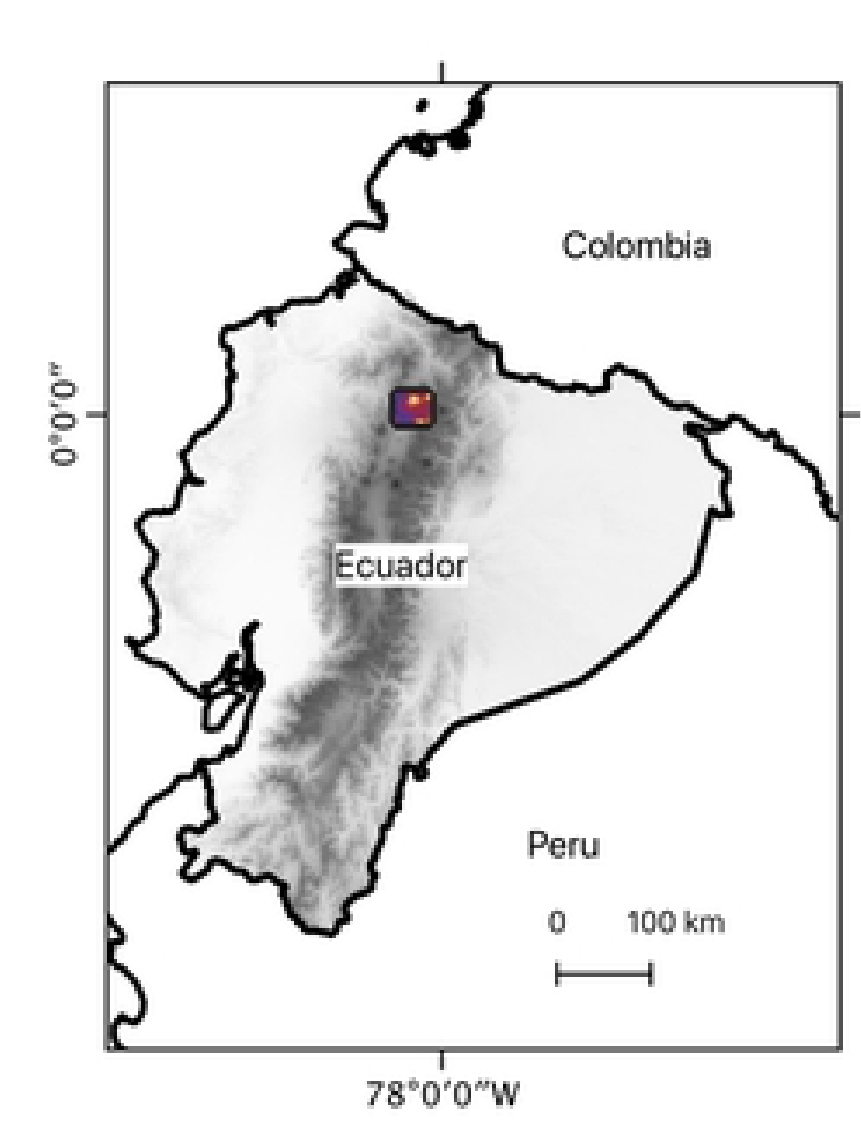

\section{Legend}

\section{Parishes}

$\square$ 1 Malchingui
$\square$ 2 Tocachi
$\square$ 3 La Esperanza
$\square$ 4 Tabacundo
$\square$ 5 Tupigachi
$\square$ Protected forest
$\square$ Water protection area
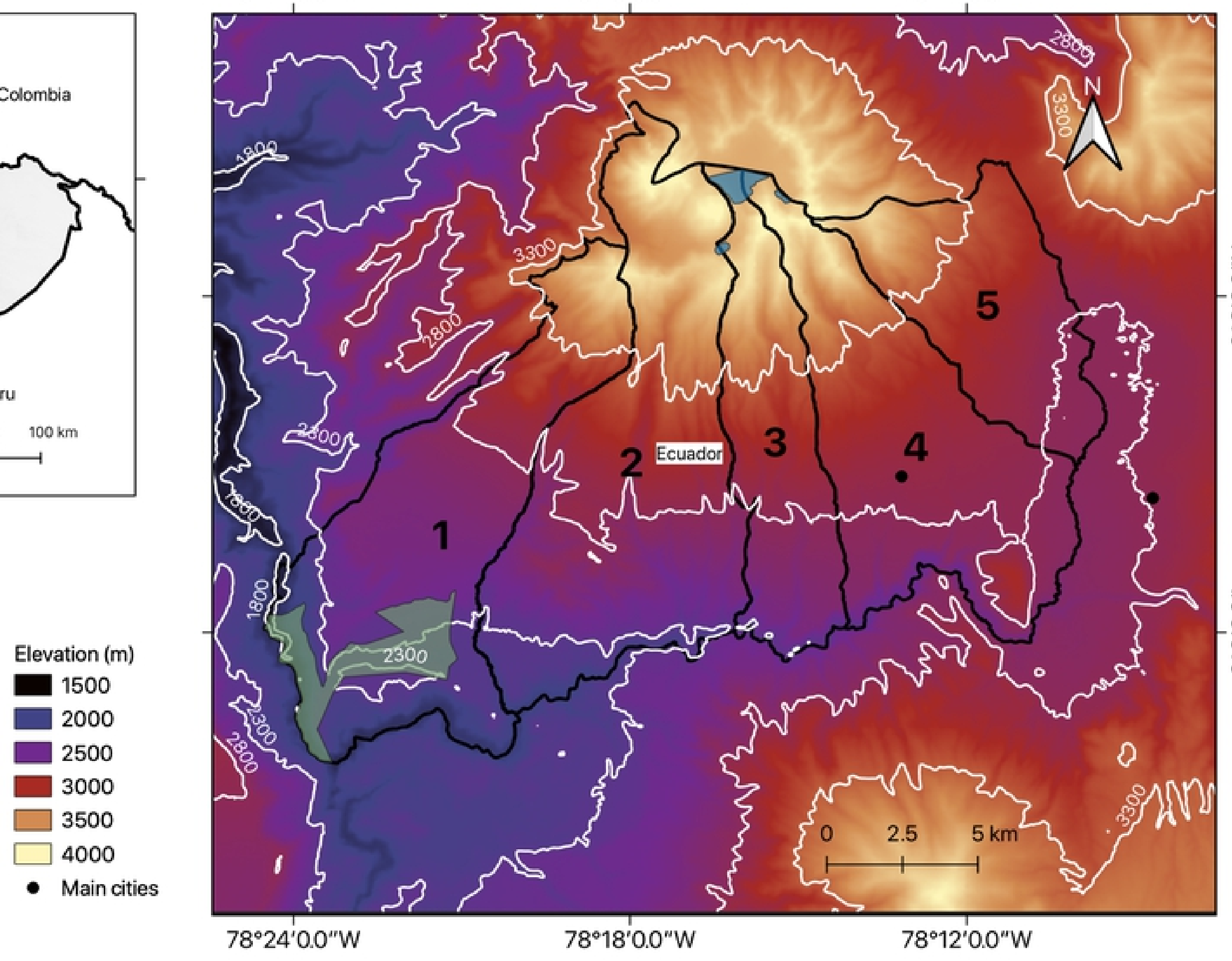

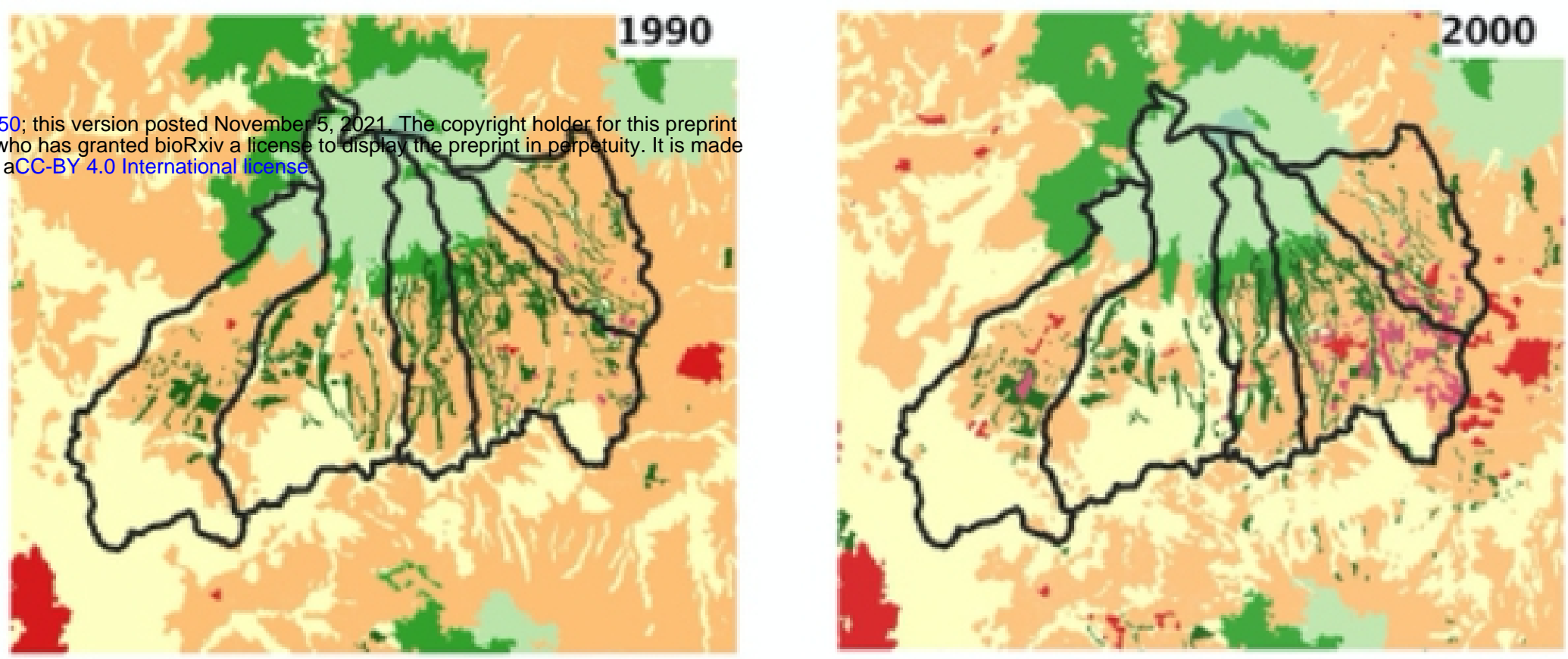

Legend

LULC classes

Agricultural land

- Floriculture crop

- Planted forests

Shrubland and herbs

Native forests

Daramo

Water bodies

Parrishes
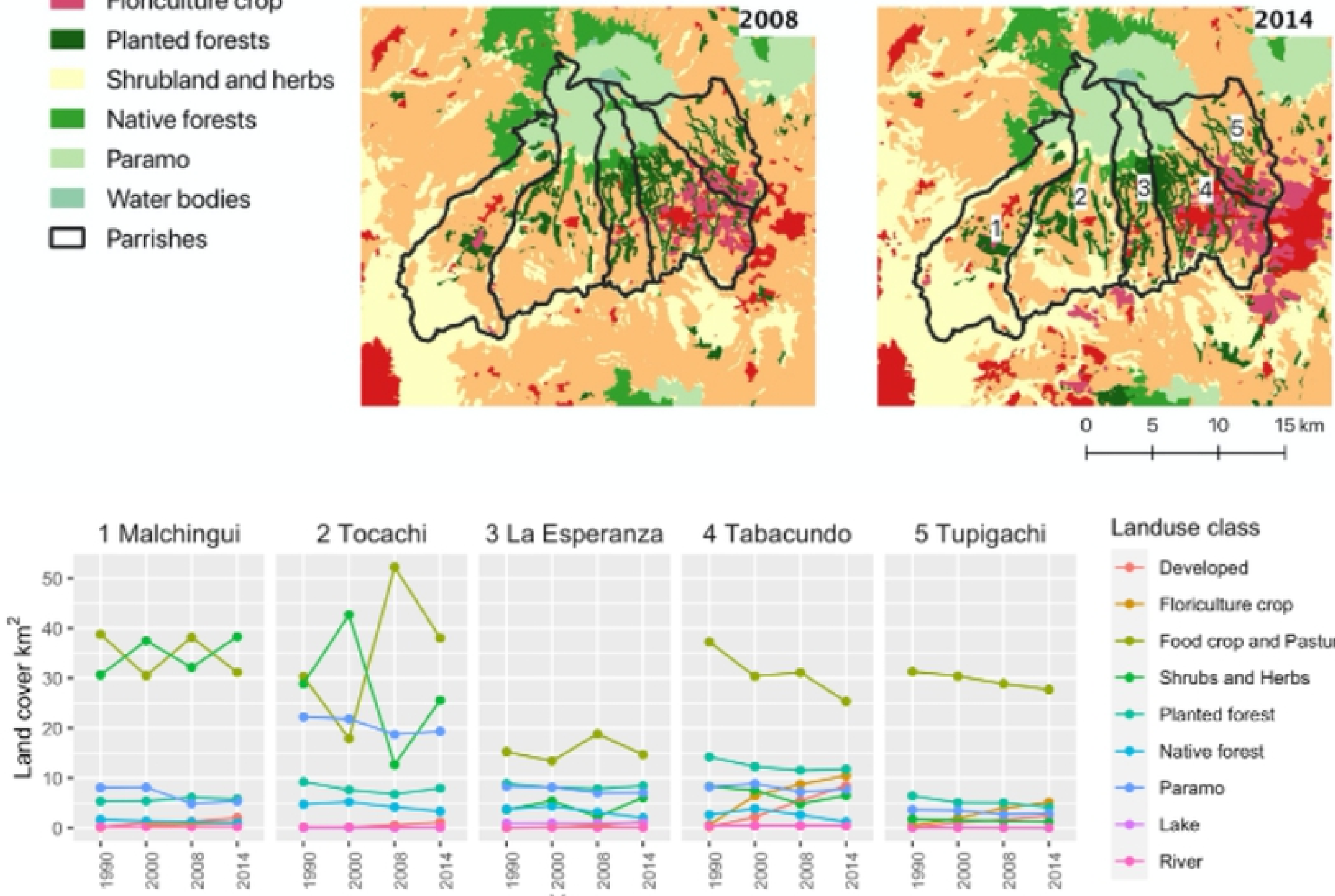

3 La Esperanza
4 Tabacundo

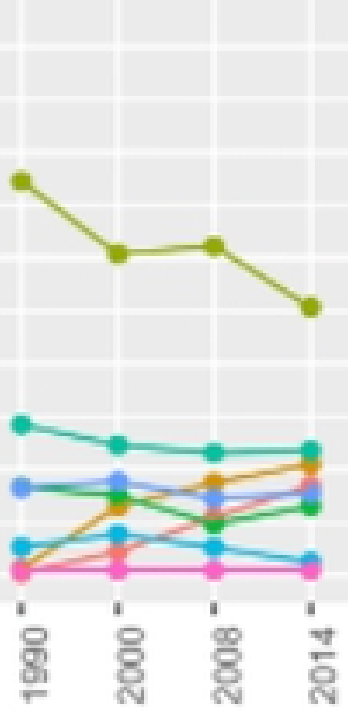

5 Tupigachi

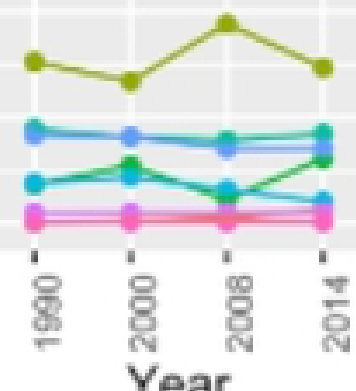

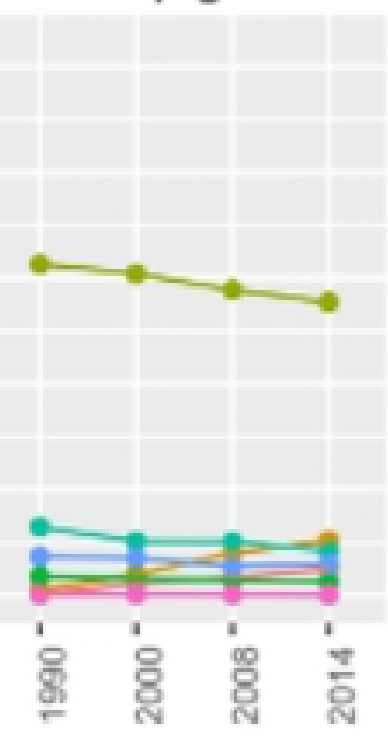

\section{Landuse class}

$\rightarrow$ Developed

$\because$ Floriculture crop

- Food crop and Pasture

$\rightarrow-$ Shrubs and Herbs

- Planted forest

$\rightarrow$ Native forest

- - Paramo

- Lake

$\rightarrow$ River 


\section{Paramo}

Shrubs and Herbs

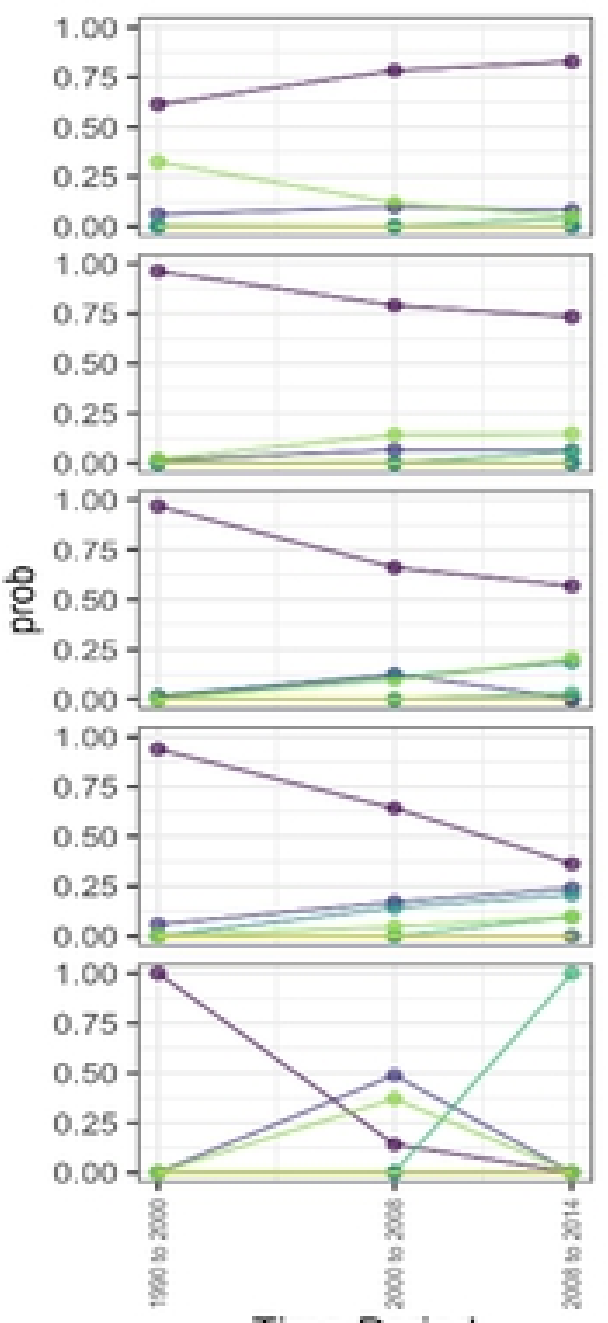

Time Period

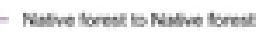

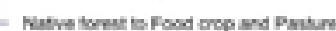

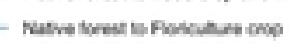

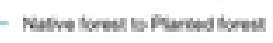

- Nabvo toentio Promo

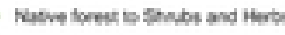

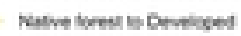

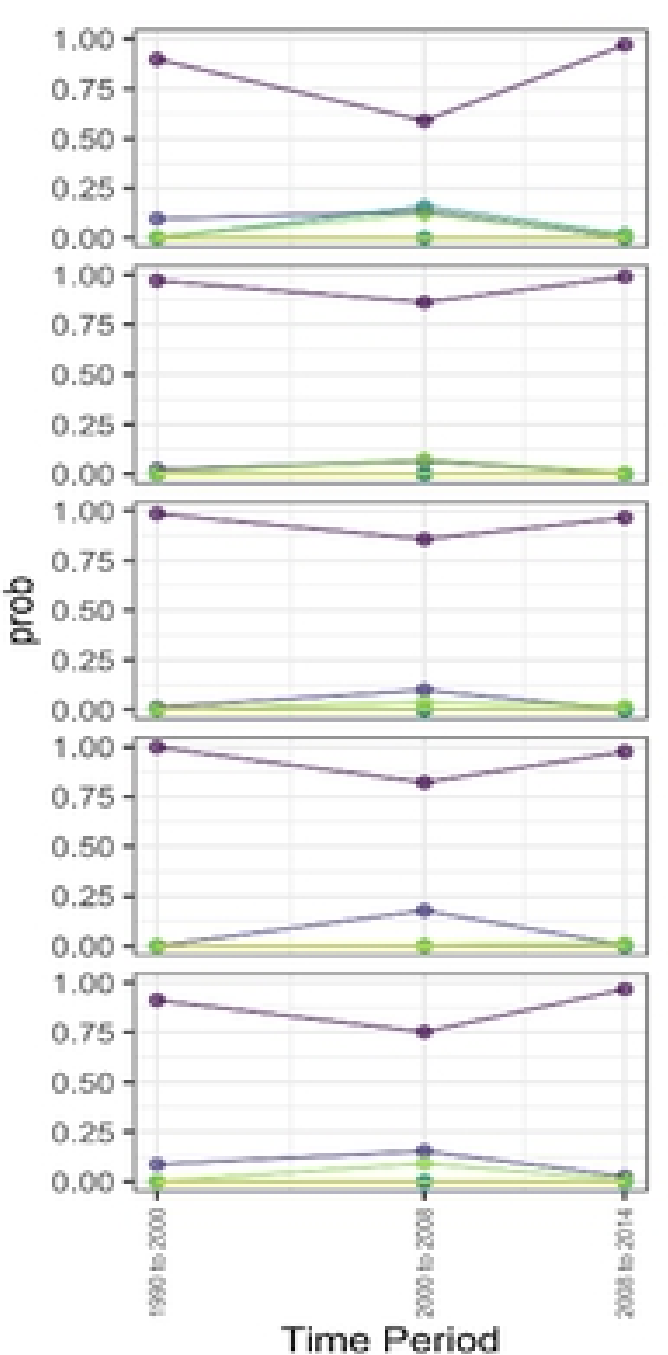

- Pranono Pramo

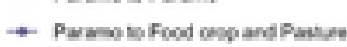

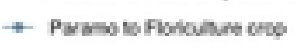

- Parmo no Pandod fores

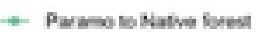

- Prasos so semos und heros

- Parmoso benticosed
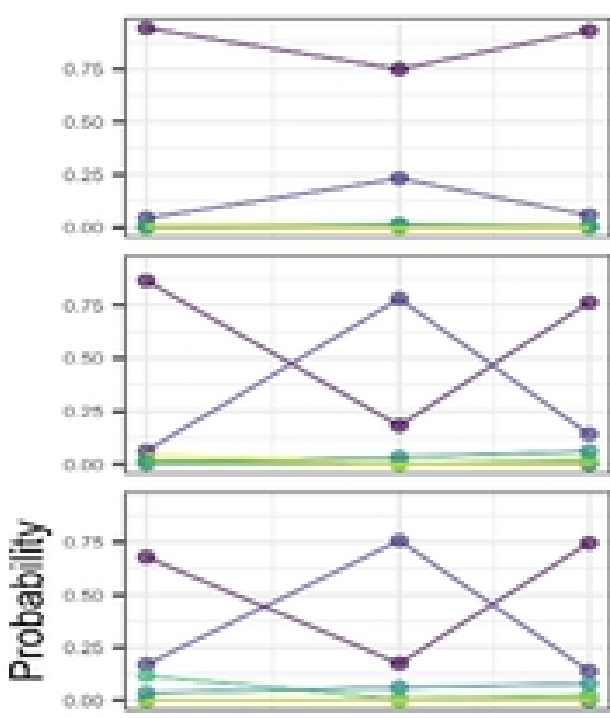

La Esperanza

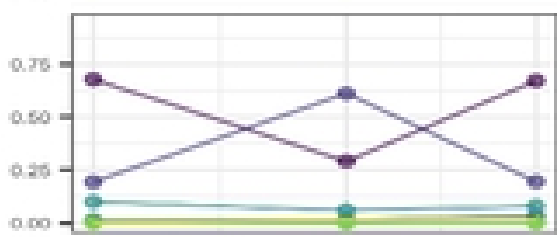

Tabacundo

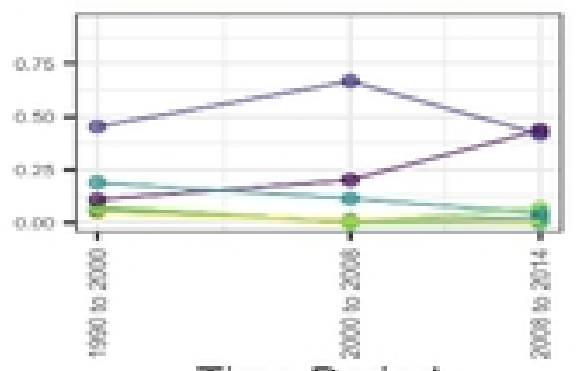

Tupigachi

Time Period

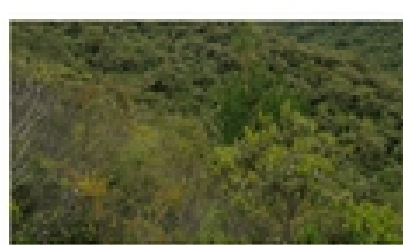

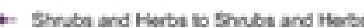

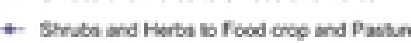

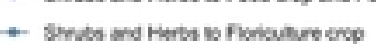

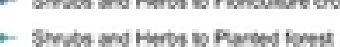

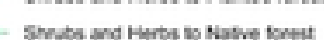

Shrien and Herter io Parmo

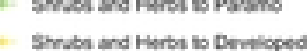

\section{1 \\ 2 \\ 3}

\section{4}

\section{5}




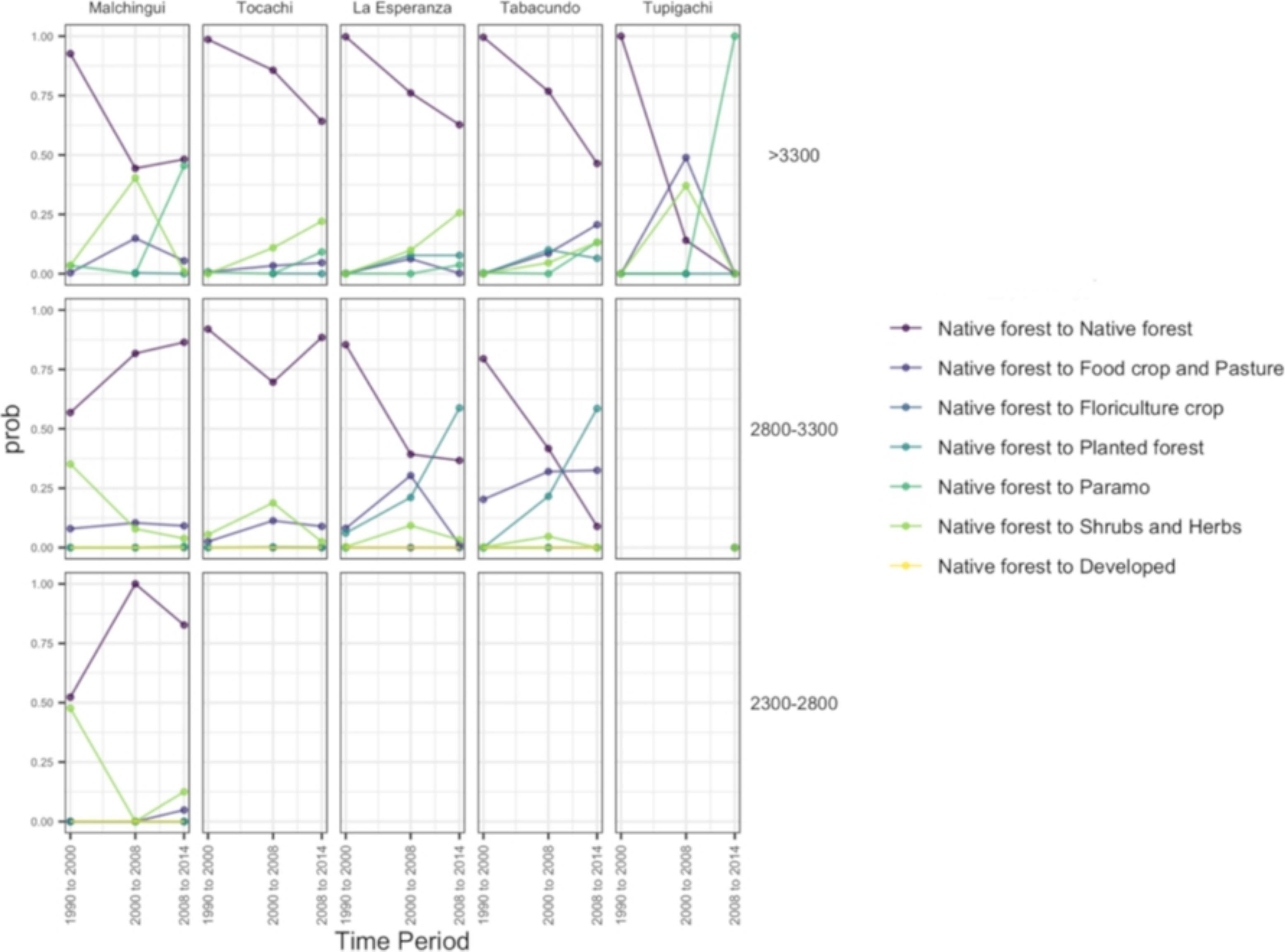




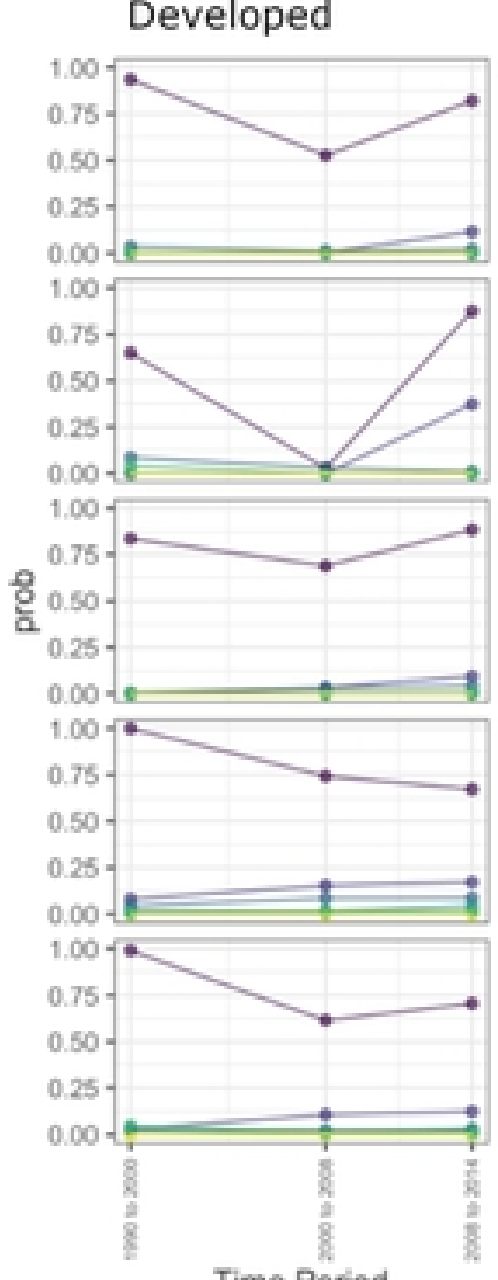

Time Period

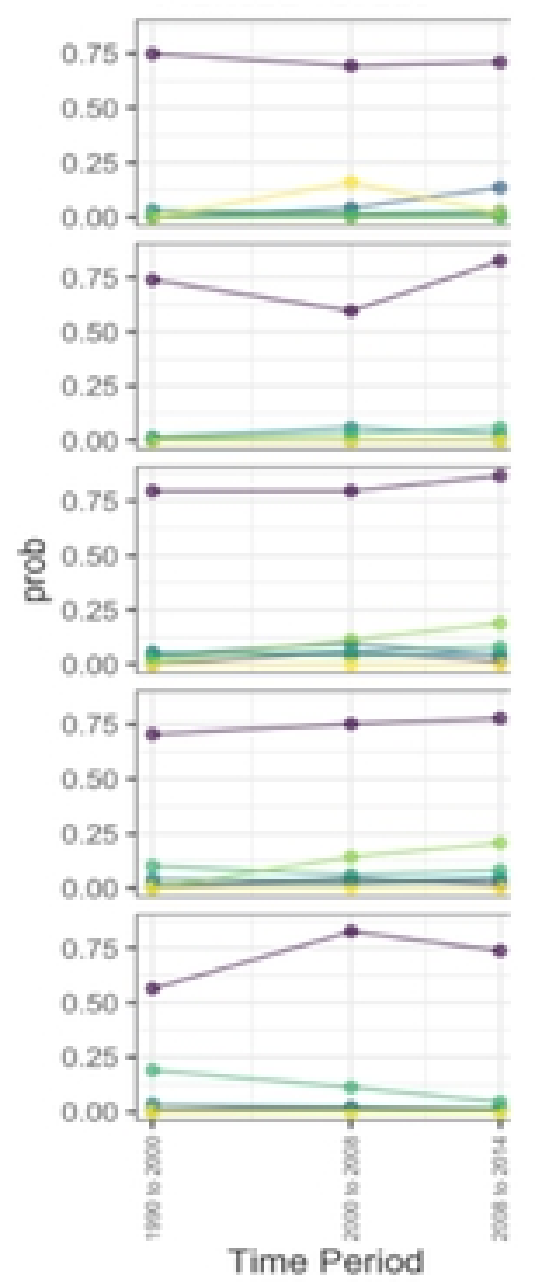

Time Period
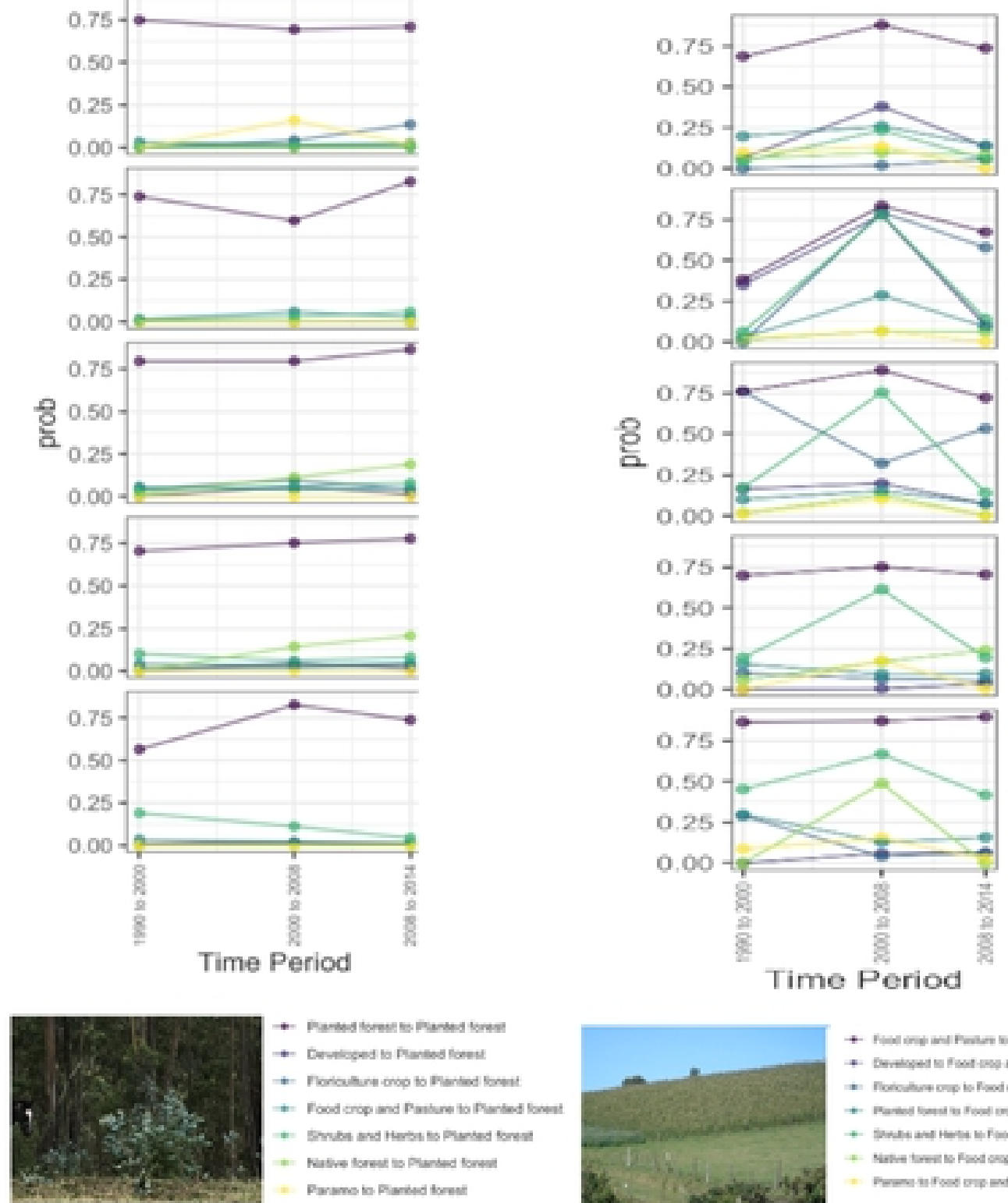

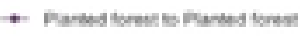

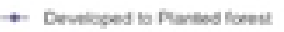

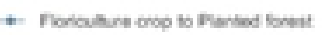

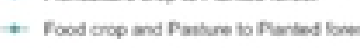

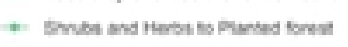

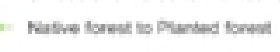
Premoso Preved torest

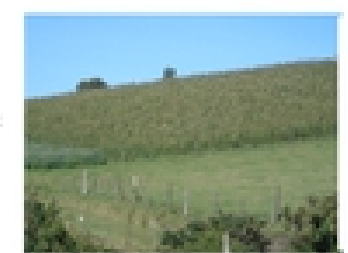

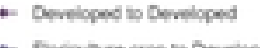

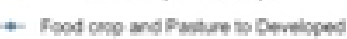

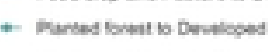

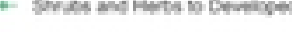
Purmo worreterest

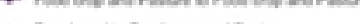

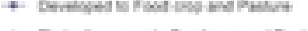

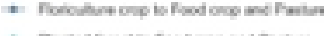

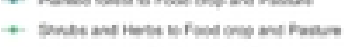

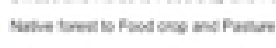

Floriculture crop

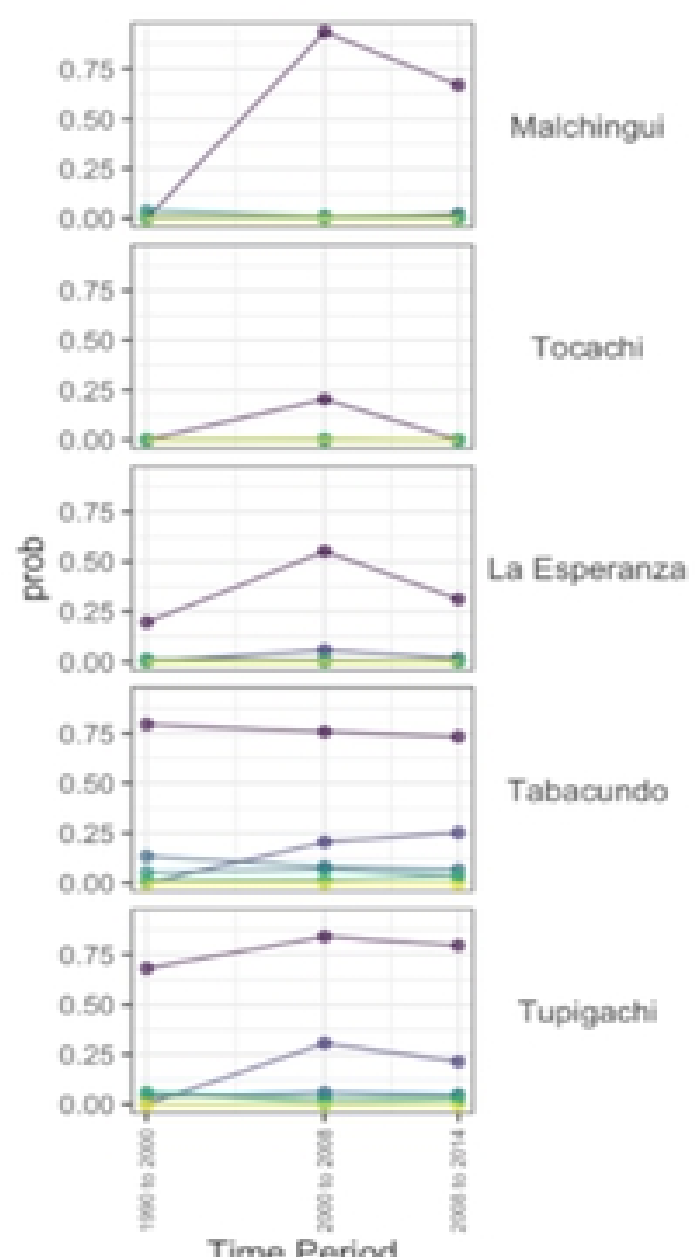

Time Period

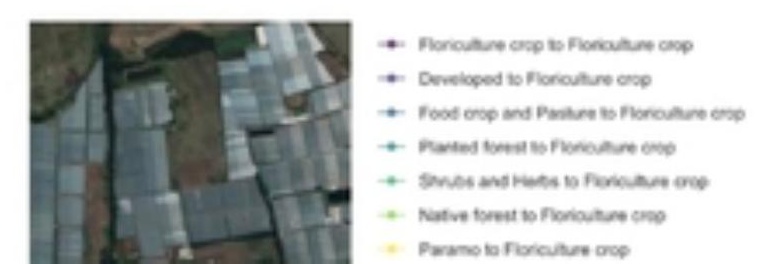


